\title{
THE HISTORY AND POLITICS OF CONTEMPORARY COMMON-LAW PURISM
}

\author{
Emile Zitzke*
}

\section{ABSTRACT}

This article explores the phenomenon of common-law purism in South Africa from a critical-legal-realist perspective, in historical context. The problem addressed in this piece is that the politics that could underlie common-law purism has not been comprehensively explored before. The problem is unpacked by conducting an archaeological study into what could be called "classical common-law purism" that once featured in the mid-1900s of South African legal history in terms of which various judges and academics committed themselves to the task of purifying the South African common law from English influences in favour of untainted RomanDutch law. In this regard close attention is paid to the lives and law of the late

* Postdoctoral Research Fellow, South African Institute for Advanced Constitutional, Public, Human Rights and International Law (A Centre of the University of Johannesburg). The idea for this paper comes from a discussion had with Johan van der Walt in Luxembourg in 2014 where I was given this valuable piece of advice: Be politically open and clear. I presented an earlier version of this paper at a seminar hosted at Saifac in October 2016 where I received helpful feedback, comments and questions from Deeksha Bhana, Stu Woolman, and David Bilchitz. Khuraisha Patel, Duard Kleyn and David Bilchitz attentively read and critiqued the article-version of the paper. I owe a part of my reading list for this work to André van der Walt who passed away towards the end of 2016, before he could read it. I dedicate this paper to his memory and legacy in private-law jurisprudence. 
Chief Justice LC Steyn and Professor JC de Wet as two prominent figures often associated with this movement, with the aim of linking the two thinkers' socialisation and political commitments to their purism. It is then shown that at the time when classical common-law purism was on its deathbed, it was rejuvenated and took on a contemporary form. The goal of the movement was no longer to purify Roman-Dutch law from English "stains"; instead, the objective became to shield the common law against a human-rights inspired Constitution. In that discussion it is demonstrated that contemporary common-law purism is currently a dominant theoretical approach, at least in the law of delict and, perhaps through a process of abstraction, in "private" law more generally. Specific attention is paid to the views of various delict academics to illustrate the prevalence of contemporary common-law purism. In that process an attempt is made to draw connections between various thinkers' socialisation, political commitments and their purism. Finally, some concluding thoughts are provided on the possible political commitments contained in the purist movement. Essentially, the invitation that is extended to private-law lawyers is to be more politically candid about what they aim to achieve, as a matter of justice, in the stances that they take on the issue of constitutional application to common-law problems.

Keywords: Constitutional avoidance; common-law purism; critical legal studies; American legal realism; critical legal realism; law and politics; constitutional application; human rights and private law; private-law theory

\section{Introduction}

This discussion is about constitutional avoidance. More specifically, constitutional avoidance as it features in common-law scholarship and practice. For brevity sake and for reasons that I hope will become clear as this paper progresses, I will refer to this type of constitutional avoidance as "contemporary common-law purism". My fundamental aim in this piece is to expose the various political stances ("ideologies", "philosophies" or "normative frameworks") that could underlie and/or be reflected in contemporary common-law purism, which has problematically remained dormant in much of the discourse on this phenomenon.

This is a problem for two main reasons. Firstly, political concealment in legal reasoning often leads to theoretical shallowness. Theoretical shallowness results in scholars misunderstanding each other, a lack of meaningful engagement and perhaps reluctance to learn from one another. To state my contention in Habermasian terms, we could appreciate each other's arguments better if we understand each other's normative claims to law's validity. ${ }^{1}$ Secondly, political secrecy in our discussions on the interaction between constitutional rights and the common law can result in erroneously-called "neutral" or "apolitical" concerns, for example "legal certainty", cloaking underlying or manifest political sentiments. Of course one could rely on

1 See, generally, Habermas 1992. 
legal certainty as a justification for following the contemporary common-law purist paradigm, but then one should be clearer about the normative importance of legal certainty for the "post"-colonial, "post"-apartheid democratic South Africa. The importance of legal certainty for the current South African condition is at present an under-theorised concept in our private-law scholarship that I will later show is sometimes invoked as an absolute necessity with no deeper attempt at justification.

I conduct my analysis firstly by endeavouring to discover the historical roots of the problem. I do this, in Part 2, by conducting a brief archaeological study into what could be called "classical common-law purism" that once featured in the mid1900s of South African legal history in terms of which various judges and academics committed themselves to the task of purifying the South African common law from English influences in favour of untainted Roman-Dutch law. In this regard I will pay close attention to the lives and law of the late Chief Justice LC Steyn and Professor JC de Wet as two prominent figures often associated with this movement, with the aim of linking the two thinkers' socialisation and political commitments to their purism.

In Part 3, I will show that at the time when classical common-law purism was on its deathbed, it was rejuvenated and took on a contemporary form. The goal of the movement was no longer to purify Roman-Dutch law from English "stains"; instead, the objective became to shield the common law against a human-rights inspired Constitution. ${ }^{2}$ In this discussion I will demonstrate that contemporary common-law purism is currently a dominant theoretical approach, at least in the law of delict and, perhaps through a process of abstraction, in "private" law more generally. I specifically look at the views of various delict academics to illustrate the prevalence of contemporary common-law purism. In that process I once again attempt to draw connections between various thinkers' socialisation, political commitments and their purism.

Finally, in Part 4, I attempt to provide some concluding thoughts on the possible political commitments contained in the purist movement. Essentially, the invitation that I extend to private-law lawyers is to be more politically candid about what they aim to achieve in the stances that they take on the issue of constitutional application to common-law problems. The invitation serves the purpose of endorsing "critical legal realism" as a theoretical framework for understanding different positions on the Constitution's application to the common law. Critical legal realism, as I use the term, integrates key assumptions of two paradigms, namely "American legal realism" and "critical legal studies". ${ }^{3}$

2 The Constitution of the Republic of South Africa Act 200 of 1993 (hereafter "the 1993 Constitution") was the first South African Constitution to contain and promote human rights which was taken up in the Constitution of the Republic of South Africa, 1996 (hereafter "the Constitution"). 
In essence the legal realists of the early 1920s argued that, among many other things, judges are unavoidably influenced by their psychological and sociological dispositions in the process of reasoning their judgments, that, when coupled with gaps and ambiguities in legal texts, results in law's indeterminacy. ${ }^{4}$ For example, one could argue that judges with liberal politics often tried to subvert apartheid policies that allowed arbitrary arrest and detention through processes of creative legal interpretation, ${ }^{5}$ or that a white middle-class judge who recently decided that the singing of dubul'ibhunu constitutes hate speech was probably influenced by his race and class. ${ }^{6}$

Critical legal scholarship of the 1970s drew on the ideas of the realists but took on the view that the law is radically indeterminate because of political conflicts that arise from within legal provisions themselves. ${ }^{7}$ The early critics reasoned that legal texts are internally conflicted because on one legal issue we could find competing political concerns at play. ${ }^{8}$ For example, one legal provision relevant to a specific issue might allow individuals to act selfishly (arguably supporting an "individualistic" politics that could be described as being "classically liberal" or perhaps "libertarian"), while another legal provision relevant to the same issue might require individuals to look out for one another (arguably supporting an "altruistic" politics that corresponds with "egalitarian" or even "socialist" concerns). In other words, the law is radically indeterminate because the law itself provides different political options to choose from. ${ }^{9}$ Furthermore, the critics argue that even where political conflicts do not arise in the law, many simple legal provisions have political manifestations. For example, a right to virtually absolute private-property ownership cannot be said to be a neutral right - it certainly has classically liberal and capitalist ideological underpinnings that are not necessarily natural and inescapable. ${ }^{10}$

When the thoughts of the realists and critics collide, we could argue that the space of legal interpretation is the field in which the political pliability of legal texts

3 See a similar merger of the two schools of thought conducted by Hanson \& Yosifon 2003: 179ff. Without expressly using the phrase "critical legal realism", Visser 1989: 21-22 appears to promote a similar approach. $C f$ Albertyn \& Davis 2010: 190 who use the term "critical legal realism" as a synonym for "critical legal studies".

4 A lucid and succinct account of American legal realism can be found in Engle 2010: 69ff. More detailed accounts of the history of the movement are provided by Singer 1988 and Tamanaha 2009. For the South African context see, eg, Dugard 1971; Hoctor 2004: 158ff; and Van Blerk 1998: 55-81.

5 Dugard 1971: 190-195.

6 Modiri 2013: 280ff.

7 On the link between American legal realism and critical legal studies see, eg, Anonymous 1982; White 1986; Engle 2010; and Albertyn \& Davis 2010: 192ff.

8 Cogent accounts of the history and concerns of critical legal studies are provided by Unger 1983; and Tushnet 1991. South African accounts of the basic principles of critical legal scholarship feature in, eg, Van Doren 1989; Van Blerk 1996; Van Blerk 1998: 147-170; and Le Roux \& Van Marle 2004.

9 This is classical critical legal studies, first introduced by Kennedy 1976.

10 See the literature canvassed in Zitzke 2014. 
and a lawyer's personal political make-up often meet. In the context of constitutional application to the common law, constitutional jurisprudence may be exploited in either direction - to apply or not to apply the Constitution - due to various political conflicts inherent in the text of the Constitution itself. Even though bordering on oversimplification, we could consider the following basic examples: Section 8 of the 1996 Constitution requires courts to develop the common law in order to further constitutional rights which supporters of the liberal rights paradigm might support; section 39(2) of the 1996 Constitution could be understood to mean that the common law must be developed if it falls short of the flexible standard of the "spirit, purport and objects of the Bill of Rights" which supporters of more critical schools of thought could support because elastic standards tend to result in more socially just outcomes; and section 39(3) and Schedule 6 of the 1996 Constitution could be read to mean that the common law must be presumed to be constitutionally compliant unless some flagrant discord exists, a sentiment that supporters of anti-human-rights movements could find valuable. For some lawyers this basic reduction of the interplay between personal politics and approaches to constitutional application will be reflective of the truth. However, for others, their politics is not unidimensional and so different situations will call for different approaches to the issue of constitutional application. Undoubtedly, for many of us, personal politics is continuously subject to change and development and thus stances on constitutional application may also change over time.

In summary, my argument is that when a judge or an academic takes a stand about the Constitution's application to the common law, their personal political make-up (no matter how simple, complex or consistent) will very often influence their decision about which interpretation of the Constitution they should follow, and that - in turn - has political results. I specifically emphasise that personal politics "very often" (not "always") will influence one's opinion on constitutional application because it is possible that the socialising effect of legal training can cause a lawyer to experience an estrangement of his or her personal politics and approach to constitutional application.

Karl Klare famously observed in the early years of South African democracy that a serious dissonance exists between the substance of the Constitution and the types of legal reasoning that South African lawyers find persuasive. ${ }^{11}$ On one interpretation of Klare's work, we could stretch his uneasiness about South African legal culture so far as to say that some lawyers with progressive mindsets, committed to the transformative potential of the Constitution, might stifle the realisation of their own political goals because they have been trained to think and reason the private law "pure". ${ }^{12}$ This does not mean that if your personal politics and 
approach to constitutional application have no clear link that you can avoid political accountability.

Of course, regardless of the link between your personal politics and your approach to constitutional application, the choice that you exercise with regard to constitutional application in a given situation will have manifest political results. ${ }^{13}$ For example, suppose that we are back in 2004 before Minister of Home Affairs $v$ Fourie was heard. ${ }^{14}$ On the issue of same-sex marriage it is possible that a hypothetical scholar might have picketed over weekends for the recognition of the equal worth of gay people while writing articles during the week for law journals about how the common-law definition of marriage, restricted to heterosexual marriage, had to be preserved for the sake of the institutional integrity of the common law. Suppose further that in the scholar's writings she made no argument for legislative intervention instead of common-law development because, in her mind, "law and politics have nothing to do with one other". Stranger things have happened. What must be emphasised in this regard is that the stance taken in the scholar's academic argument had the manifest political effect of stifling the social transformation that the scholar was fighting for in her private time. It might not have been her direct intention but that is the effect of her jurisprudence.

It is against the backdrop of critical legal realism that this paper should be understood. The key idea that I promote here is this: The possibility exists that if we, as private lawyers, are politically clearer about why we generally, as a matter of justice (and not just black-letter law), endorse or reject the Constitution's reach into private law, we could all deepen our theoretical understanding of this issue and perhaps this could open a new level of discourse that is both enlightening and exciting. Even if our personal politics does not comfortably fit with our reading of the law on constitutional application, I think it is worthwhile identifying the clash and then to proceed to explain what the underlying ideology of each is, why we think the inharmoniousness exists, and which of the clashing options are more desirable.

\section{Classical common-law purism}

\section{The historical backdrop}

Classical common-law purism (in traditional literature simply called "purism") involves the cleansing of South African common law from English influences with the ultimate goal of creating and maintaining an unmixed system of Roman-Dutch

12 This point is to some extent echoed in Davis \& Klare 2010: 406.

13 See eg Botha 2004.

14 Minister of Home Affairs v Fourie 2006 (1) SA 524 (CC) is the much-celebrated decision in which the Constitutional Court held that the common-law definition of marriage was unconstitutional on the basis that it unfairly discriminated against homosexual people who were excluded from its ambit. The Court instructed Parliament to pass national legislation that would make provision for same-sex legal unions. This legislation was later passed as the Civil Union Act 17 of 2006. 
law. The apparent conflict between the Englishness and Roman-Dutch character of our common law must be understood against the backdrop of the socio-political conditions of South Africa in its early colonial history. To use the phraseology of Daniël Visser (from whom I also borrow the idea of linking external legal history to the development of jurisprudential paradigms), classical purism must in some way be connected to the "cultural forces" at play during its inception. ${ }^{15}$

The source of law that South Africans know today as common law came about as a result of two official conquests. After the Dutch East India Company arrived at the Cape in 1652 they eventually decided to colonise the territory in the name of the Dutch Republic and impose their laws onto African people. ${ }^{16}$ Colonisation was possible because the conquerors regarded the inhabitants as uncivilised and therefore their territories were deemed terra nullius. But the process of colonisation did not only involve the displacement of African political and economic power. ${ }^{17}$ It also involved epistemicide - the killing of existing forms of knowledge and the subsequent prevention of the development of that knowledge. Following Frantz Fanon, colonisation had at its heart the effect of pushing Black lives into the "zone of non-being"18 through a process of external (material) and internal (psychological) othering. ${ }^{19}$ Part of the epistemicidal effects of colonisation certainly related to the death of culture and language, but for purposes of present discussion it must be emphasised that a crucial effect was the discarding of African law and its replacement with a Dutch-inspired legal system. If no Cape-specific administrative legislation was passed on a specific issue, the laws of Holland (including the commentary thereon by the Old Dutch writers), the Batavian placaaten, and Roman law applied. ${ }^{20}$ During this time, the Afrikaans-speaking farming community of Dutch settlers, French Huguenots and other European immigrants became known as the Boers. Later they would be called Afrikaners.

The British occupied the Cape in 1795 for the first time, interrupted between 1803 and 1806 by Dutch rule, after which the British finally took control of the area in 1806. ${ }^{21}$ Under English rule the precedent laid down in Campbell $v$ Hall ${ }^{22}$ was followed in terms of which the legal status quo had to continue subject to incremental changes brought about by the British colonial authorities. ${ }^{23}$ The effect was that Roman-Dutch law largely remained intact. The most significant English

15 Visser 2003.

16 See, eg, Van Niekerk 2011: 20-21.

17 See, eg, Terreblanche 2002: 153-155.

18 Fanon 1967: 2.

19 Idem 8.

20 Wessels 1920; Hahlo \& Kahn 1968: 574; Van Zyl 1971: 434ff; and Thomas et al 2000: 96-97.

21 Hahlo \& Kahn 1968: 575; Van Zyl 1971: 443; and Thomas et al 2000: 97.

22 Campbell v Hall (1774) 1 Cowp 204 at 209, 98 ER 1045 at 1047.

23 Hahlo \& Kahn 1968: 575; Van Zyl 1971: 444; and Thomas et al 2000: 97-98. 
changes related to the structure of government and the courts, as well as notable revisions to criminal, mercantile and procedural law. ${ }^{24}$

Some of the Boers eventually left the Cape to establish their own states free from English control. This process would later be called the Great Trek of 18351848. The Natal Colony of the Boers was annexed within five years by the British with the result that Roman-Dutch law with English sprinkles, as it featured in the Cape, applied. ${ }^{25}$ In the Zuid-Afrikaansche Republiek (ZAR) and the Orange Free State (OFS), Roman-Dutch law was applied. In the OFS this meant that the writings of, among others, Voet, Van Leeuwen, De Groot, Van der Linden and Van der Keesel were authoritative. ${ }^{26}$ In the Zuid-Afrikaansche Republiek the law was based on Van der Linden's Koopman's Handboek except on issues on which he was silent in which case van Leeuwen's Het Roomsch-Hollandsch Recht or the Inleidinge of De Groot would be authoritative. ${ }^{27} \mathrm{Up}$ to this point in our history it is clear that Roman-Dutch law constituted the bulk of colonial South Africa's substantive law, with English alterations featuring more strongly in the British colonies.

The battle between the Boers and the British for political control of South Africa did not end here. The South African War (1899-1902) ensued, ultimately pitting the British colonial forces against the Boer Republics. ${ }^{28}$ The Boers surrendered to the British Empire, the result eventually being the establishment of the Union of South Africa in $1910 .{ }^{29}$ The four colonies became united under the authority of the British Monarch's representative in the form of the Governor-General. ${ }^{30}$ As HR Hahlo and Ellison Kahn have shown, the laws of the colonies were carried forward into the Union. However, the court system comprised of a single Supreme Court with four provincial divisions and an appellate division. ${ }^{31}$ The result was that South Africa would now have a unified legal system that would properly be called "South African law" instead of the Roman-Dutch or English law. Despite this mirage of unity, Phillip Thomas et al indicate that during the time of the Union "the Boer War had strengthened Afrikaner nationalism with the result that South African politics during the first half of the century were dominated by English versus Afrikaner confrontation

24 Hahlo \& Kahn 1968: 576-577; Van Zyl 1971: 445; and Thomas, Van der Merwe \& Stoop 2000: 98-99.

25 Van Zyl 1971: 471-472; and Thomas, Van der Merwe \& Stoop 2000: 99-100.

26 Van Zyl 1971: 468; and Thomas, Van der Merwe \& Stoop 2000: 103.

27 Van Zyl 1971: 462-463; and Thomas, Van der Merwe \& Stoop 2000: 103-104.

28 Traditionally the term "Anglo-Boer War" is used to depict that the war was between Britain and the Boer Republics. Here, I use the term "South African War" to emphasise the fact that there were many African people who were also caught up in the hostilities between the Boers and the British. I take cognisance of the fact that there was technically no unified "South Africa" in existence at the time, but this term features prominently in modern accounts of South African history. See, eg, Thompson 2014: 132ff.

29 The South Africa Act of 1909 (9 Edw VII c 9) constituted the Union.

30 Hahlo \& Kahn 1960: 128.

31 Idem 249ff. 
at the expense of the country's black population". ${ }^{32}$ This was further exacerbated by the fact that Black people were excluded from the realm of political and economic autonomy which eventually became formalised as Apartheid. ${ }^{33}$ In truth, there was very little unity in the Union.

The battle between the Boers and the British may have come to an end in physical confrontational terms but a South African "Legal Cold War" arose in practice and scholarship. Following the South African War, many Afrikaners yearned to establish a collective identity and to recover the political power that they once had. ${ }^{34}$ To secure academic legitimacy (and even superiority) Afrikaner scholars could strategically rely on a claim that Roman-Dutch law was the "true" law of South Africa, giving them a linguistic advantage over their English counterparts. ${ }^{35}$ By the late 1940s, Afrikaner legal scholarship was in flight with a renewed interest in the pure RomanDutch law. ${ }^{36}$ Many Afrikaner academics were afforded opportunities to study in the Netherlands, while English scholars were often sent to Oxford or Cambridge. ${ }^{37}$ The divide between Afrikaner and English legal academe in South Africa was real, as illustrated by a writer with the nom de plume of Proculus who identified two competing schools of South African jurisprudence that flourished by the early $1950 \mathrm{~s}^{38}$

On the one hand "Antiquarians" specialised in the historical study of the common law, often conducting overlong analyses of the progression from Roman to Roman-Dutch law with a briefer study of South African case law on the specific issue. They often concluded their research with scathing comments directed against the South African judiciary for not strictly adhering to the Roman-Dutch position. ${ }^{39}$

On the other hand the "Modernists" would focus on South African judicial pronouncements, only returning to the old authorities where uncertainty in modern law existed. ${ }^{40}$ The Modernists took on the view that South African law was a mixture of Roman-Dutch and English law and that even though the Roman-Dutch component laid the foundation for our law, English influences could not be denied as a legitimate part of our legal system. ${ }^{41}$ Furthermore, the Modernists contended that the law necessarily develops when judges interpret rules. Even in countries with codified legal systems, the modern law contained much more detail than a plain-meaning reading of the Codes might suggest at first glance. ${ }^{42}$ According to the Modernists,

Thomas et al 2000: 104.

Terreblanche 2002: 6ff.

Visser 2003: 54.

Ibid.

Thomas at al 2000: 105.

Visser 2003: 55.

Proculus 1950.

Idem at 306.

Ibid.

41 Idem at 309.

42 Idem at 312. 
judicial developments of our common law beyond the original scope of RomanDutch rules should be accepted as legitimate as long as it "satisfactorily meets the needs of the society it serves". ${ }^{43}$

In 1952 GA Mulligan, King's Counsel at the Johannesburg Bar, redefined Proculus' problem. ${ }^{44}$ Mulligan identified a deeper issue at stake in the struggle between Antiquarians and Modernists: Hidden in Proculus' commentary is an identification of a legal battle between Afrikaner scholars who advocated a return to pure RomanDutch law and English academics who promoted the modern and local development of South African law which incorporated both Roman-Dutch and English elements. For Mulligan the Antiquarian school promoted Roman-Dutch "purism" - the first time that the phrase was used. Opposing the purists were the "pollutionists" and the "pragmatists". The pollutionists made South African law more English than might have been necessary, probably because they relied on English case law and books on account of those being more accessible and readily understandable. ${ }^{45}$ Phrased differently, in my own terms, the pollutionists suffered from English overexcitement. The pragmatists acknowledged that South African law had three parts, namely Roman-Dutch law, English law and modern South African developments of the old rules brought about by the judiciary to keep up with the advancement of society. According to the pragmatists, all three of these components had to be recognised to give a true account of the South African legal system. ${ }^{46}$ Regardless of how one divides the jurisprudential armies, the war was ultimately between the purists and non-purists, and it was a political battle.

At this point we must reflect on the ideological underpinnings of the classical purist movement. In addition to the post-South-African-War blues, it must be remembered that by 1948 Afrikaner and white supremacy reached its zenith with the formal introduction of Apartheid. In this regard Eduard Fagan contends that

it would be naïve to suggest that the racial "purity" so ardently espoused by (predominantly) Afrikaner politicians did not have its corollary in the movement in favour of "purity" in South African law - by which is meant the exclusion of what are perceived to be English additions to the pre-existing Roman-Dutch system. ${ }^{47}$

He further argues that "due attention should be given to the historical and political matrix from which the purists' claim to Roman-Dutch law's right of preeminence arose" 48 and that, even though the motivations for different classical purists could have been diverse, it certainly arose from "a political Zeitgeist which

44 Mulligan 1952.

45 Idem at 30-31.

46 Idem at 31-32. See, also, Bodenstein 1912; and Visser 1986.

47 Fagan 1996: 61

48 Idem at 63. 
was concerned, above else, with the separation of cultures" ${ }^{49}$ Even though this could be the case, François du Bois and Daniël Visser emphasise that there were those purists who definitely were inspired by Afrikaner nationalist politics, but that there were others who sincerely believed that Roman-Dutch law should remain pure for the sake of preservation of legal science and system..$^{50}$ In the next two sub-parts ( $§ 2$ $2 \& \S 23$ ) I explore to what extent politics, as opposed to the "apolitical" concerns of legal science and system, played in the reasoning of judges and academics of the time. It would be an impossible task to explore every academic and judge's lawand-politics relationship. For that reason I have decided to consider the lives and law of two prominent figures in the classical-purist movement. In part, I consider these two individuals because much has been written about them as humans and as lawyers. But also - in part - I must concede, because their stories support aspects of the critical-legal-realist insight. The two figures are the late Chief Justice LC Steyn (1903-1976) and Professor JC de Wet (1912-1990).

\section{Classical purism as nationalism: LC Steyn}

After growing up in a pro-Nationalist environment and attending anti-English schools,$^{51}$ Lucas Cornelius Steyn was employed as a legal advisor to the South African government in various capacities ${ }^{52}$ until he was appointed to the Transvaal Provincial Division of the Supreme Court in 1951 at the age of forty-seven. Within four years he was promoted to the Appellate Division and by 1959 he became the Chief Justice of South Africa. ${ }^{53}$ These introductory facts are important because Edwin Cameron claims that a link exists between them and Steyn's "executiveminded" and "chauvinist" jurisprudence. His jurisprudence is said to have been executively-minded because he more often than not adjudicated cases in favour of government with little to no consideration for individual liberty. His jurisprudence was additionally chauvinist because he often foisted classical purist ideals on our law, not for the sake of functionality and development but simply for the sake of cultural purity.

Steyn was the Nationalist government's man. He served as legal advisor to the state departments of external affairs and justice, during which he represented South Africa under Nationalist rule at various United Nations assemblies. ${ }^{54}$ Even though he could comfortably be described as a "public servant", due to the nature of his employment he also fulfilled an instrumental role in the building of the Nationalist

Idem at 64.

50 Du Bois \& Visser 2003: 619; repeated in Du Bois 2004: 224.

51 Cameron 1982: 38.

52 Kahn 1971: 1.

53 Idem at 2.

54 Idem at 1-2. 
state as a politician. The Nationalist state's political ideology was constructed on the foundational belief in purity of all kinds. As explained above, at least one leg of purism related to the decontamination of various South African institutions from Englishness. By means of examples, immigration laws were introduced to make it more difficult for English people to move to South Africa; the Rand Afrikaans University was established in 1967 to promote Afrikaans as an academic language and was led by the Nationalist cabinet minister Nic Diederichs who later became state president; and South Africa became a Republic independent from British control in $1961 .{ }^{55}$ One might object and claim that Steyn's appointment to the bench in 1951 was not political and that he was appointed on merit, being a holder of a doctoral degree from the University of Stellenbosch and an author of a famous book on statutory interpretation. ${ }^{56}$ Unfortunately there is evidence that his competence may have been a strategic consideration that hid the true reason for his appointment, which was his commitment to Nationalist politics. As Edwin Cameron says, "his legal philosophy was of a piece with the broader pattern of nationalism then ineluctably being impressed upon the life of the country". ${ }^{57}$ This made him a suitable candidate for the office of Chief Justice despite him being junior to the liberal and English Appellate Division judge Oliver Schreiner, who was not one of the government's favourites. ${ }^{58}$

Steyn's commitment to Nationalist politics is reflected in various executiveminded decisions on statutory interpretation in which he favoured the government at the expense of protecting the freedom of the individual. ${ }^{59}$ Such decisions were not necessarily corrupt in the sense that his pronouncements were fettered by governmental powers, but they were morally corrupt and laid many bricks towards the building of the Apartheid state. ${ }^{60}$ More pertinently for purposes of the present discussion it must be emphasised that Steyn's Nationalism also influenced his approach to common-law problems.

As a symbol of racial and cultural purism, Steyn attempted to shave away as many English influences on our law as possible. Although there are many, ${ }^{61}$ one

55 Cameron 1982: 41.

56 Kahn 1971: 1.

57 Cameron 1982: 42.

58 Idem at 41-42.

59 See, eg, his judgments or concurrences commented on by Cameron 1982: 53ff: Lekhari v Johannesburg City Council 1956 (1) SA 552 (A); Collins v Minister of the Interior 1957 (1) SA 552 (A); Minister of the Interior v Machadodorp Investments 1957 (2) SA 392 (A); Publications Control Board v William Heinemann 1965 (4) SA 137 (A); South African Defence and Aid Fund v Minister of Justice 1967 (1) SA 263 (A); Cassem v Oos-Kaapse Komitee van die Groepsgebiederaad 1959 (3) SA 651 (A); Down v Malan NO 1960 (2) SA 734 (A); Group Areas Development Board v Hurley NO 1961 (1) SA 123 (A); Minister of the Interior v Lockhat 1961 (2) SA 587 (A); Loza v Police Station Commander, Durbanville 1964 (2) SA 545 (A); Rossouw v Sachs 1964 (2) SA 551 (A); and Schermbrucker v Klindt NO 1965 (4) SA 606 (A).

60 Cameron 1982: 52; $c f$ Dyzenhaus 1982.

61 See the nineteen-page case review of Steyn's impact on South African law by Rumpff 1978: 87106. 
well-known example that I will focus on here is Regal $v$ African Superslate. ${ }^{62}$ In Regal a dispute arose between the owners of adjacent properties. Regal sought an interdict to prohibit African Superslate from continuing to allow refuse slate to be deposited in an adjacent river, causing the slate to wash onto Regal's property.

For more than eighty years since Holland $v$ Scott ${ }^{63}$ South African courts had relied on the English law of nuisance to resolve disputes of this nature. Nevertheless, Chief Justice Steyn thought it prudent to disrupt the longstanding principles of nuisance because English law was not "our common law". ${ }^{64}$ According to Steyn, English nuisance law was imported under the guise that it was compatible with the Romanist principles that "it is prohibited to do on your own property that which may harm another's" and "do not use your own property to do harm to another", but that the similarity between the English and Romanist rules of neighbour law were "nothing more than coincidental", and that "our law" cannot be replaced by the English law of nuisance. ${ }^{65}$ As explained in the preceding discussion, South African law is a mixture of Roman-Dutch and English law as developed by our courts. "Our common law" should therefore be accepted as a hybrid system law. Not so, according to Chief Justice Steyn. In the remainder of the judgment, Steyn meticulously explained what the Codex and Digesta of the Roman Emperor Justinian had to say about the legal relationship between neighbours, what Dutch and German authors thought of it, and held that these views constituted "our law".

For Steyn, the term "our common law" meant Roman law as received in Western Europe. The "our" did not signify a united South African people; the "our" referred to Afrikaners. The possibility also does not seem to exist to save Steyn's purism in Regal on the ground of legal certainty, system or science. Steyn disrupted eighty years' worth of law - legal certainty was clearly not his objective. Legal systematisation or science was also not on the agenda because, in Steyn's own words, the Roman-Dutch position was "fragmented" and existed in a time and context of different remedies and procedural rules that were very different to our own. ${ }^{66}$ In fact, various neighbourlaw remedies recognised in Roman-Dutch law had fallen into disuse, ${ }^{67}$ but Steyn was adamant that the Roman-Dutch position was relevant for modern South African law. Steyn's reasoning in Regal was critiqued by AS Mathews and JRL Milton because

it is still undesirable that a doctrine which the courts have explicitly adopted (or taken for granted) for more than eighty years should be subverted without any consideration of the extent to which it achieved a just solution of conflicts and to which it reflected desirable social policy. It is notable that policy considerations are entirely overlooked [...] in the judgments delivered in Regal's case. ${ }^{68}$

$621963(1)$ SA $102(A)$.

63 (1882) 2 E.D.C. 307.

64 Regal v African Superslate at 106D.

65 Idem at $106 \mathrm{~F}$.

66 Idem at $106 \mathrm{H}$.

67 Idem at $109 \mathrm{H}$.

68 Mathews \& Milton 1965: 40. 
In short, Steyn purified the common law, simply for the sake of purity with no consideration given to established rules (that would keep many formalists happy), reputable principles (which Dworkinians would support) or good policy (punted for by more critical scholars), and without any regard being had for the fact that "[o] ur pride in our national jurisprudence is rightly based on its inherent merits, not the purity of its ancestry". ${ }^{69}$ Cameron is then surely correct when he describes Steyn's jurisprudence as chauvinist and inextricably linked to his Nationalist politics. Moreover, I argue that Steyn's executive-mindedness is circumstantial evidence supporting the claim that his purism was politically motivated. However, not all classical purists were inspired by Nationalism like Steyn may have been.

\section{Classical purism as liberal deviationist doctrine: JC de Wet}

Professor JC de Wet is conventionally considered to be the "head boy" of the classical purist movement in South African legal academia and was a much-loved academic who taught at Stellenbosch (1936-1972) and the University of Cape Town (19761981). I say he was much-loved because two Festschriften honour his legacy, ${ }^{70}$ providing us with enough academic literature to draw tentative links between his politics, academic socialisation and jurisprudence. There are two comments to be made here about De Wet, both of which emphasise that his purism was not influenced by Afrikaner-Nationalist politics. Firstly, there is evidence that shows that De Wet's purism was not absolutist. Secondly, there is evidence that De Wet was a devoted liberal and perhaps there may be snippets of data that show that his purism and liberal politics were in fact intertwined.

Even though it is true that De Wet more often than not favoured a pure RomanDutch version of the common law, he never threw the baby out with the bathwater. De Wet was willing to accept that English law sometimes provided better solutions to South African legal problems than the Roman-Dutch rules. ${ }^{71}$ In general terms De Wet regarded English law as being "unsystematic" in comparison to RomanDutch law, but he nevertheless made it clear that there are instances where we can learn from English law. ${ }^{72}$ Thus, his approach to the common law probably cannot comfortably be described as being Antiquarian. De Wet did not simply want a return to Roman-Dutch law - his approach made room for the development of the common law drawing from a wide variety of intellectual resources, promoting those rules and principles that were grounded in "reason" and "equity". ${ }^{73}$ This leads us to De Wet's politics.

70 Gauntlett 1979; Du Plessis \& Lubbe 2013.

71 See, generally, Van Niekerk 1980: 186-187; Van Blerk 1982: 374.

72 Du Bois \& Visser 2003: 619.

73 Van Niekerk 1980: 186. 
It has been repeatedly emphasised by De Wet's biographers that his purism was not influenced by "nationalism"74 or "chauvinism" "75 (after all, he was married to an atheist English woman called Hilda who voted for the Progressive Party ${ }^{76}$ but by his desire for "system" and "science" in law. With that said, there are interesting links to be drawn between his politics and his jurisprudence. De Wet practiced liberal politics by, for example, speaking out against intimidation tactics of the National Party (NP), stood as an independent candidate in the city council where he took a clear position in promoting a multiracial vision for South Africa, and opposed the removal of coloured people from Stellenbosch. ${ }^{77}$ In this sense we could argue that De Wet embraced the ideals of the Enlightenment (or, as critical scholars like to call it, "Western Modernity") from which flows his support for the (a) scientific and systematic study of law, and (b) infiltration of liberal philosophy into activism and the law. Let us consider two examples to illustrate this point.

Before De Wet's prolific work on South African criminal law called Strafreg, ${ }^{78}$ criminal liability was objectively determined under the influence of English law. De Wet took on the viewpoint that justice must mean justice for the "individual in the dock" and thus he supported a subjective approach to criminal liability as it featured in the Continental systems. ${ }^{79}$ Therefore, for De Wet, an accused's conduct must be subjectively blameworthy: the doctrine of versari in re illicita had to fall (and judging by his witty and comical writing style, I am sure he would have footnoted \#VersariMustFall if hashtags had existed back then); ignorance of the law had to be a valid defence against an allegation of dolus; and so on ${ }^{80}$ In the case of the nature of the fault enquiry in criminal law, De Wet may well have pushed for legal reform, through a reinvigoration of the Roman-Dutch tradition, with the underlying motivation of creating a more liberal version of South African society and law. Compare LC Steyn: He also held the view that versari had to be done away with in $S v$ Bernardus.$^{81}$ However, similar to his judgment in Regal discussed above, Steyn was not primarily concerned with reasoning whether or not versari was just and equitable. His main concern was that versari was not reconcilable with later RomanDutch writings. FLH Rumpff, who seems to have praised Steyn's jurisprudence, notes that Steyn probably decided Bernardus in the way that he did under the influence of his purist teacher Professor HDJ Bodenstein. ${ }^{82}$ Thus we can argue that Steyn's justification for eradicating versari from South African criminal law was based on

\section{Idem at 187.}

Du Bois \& Visser 2003: 619.

Van Wyk 2013: 48-50.

Idem 47-48; and Froneman 2014: 476.

De Wet \& Swanepoel 1949. The fourth edition of this work was published in 1985.

Van Niekerk 1980: 187; and Van Blerk 1982: 371.

See the overview provided by Snyman 2013: $351 \mathrm{ff}$.

1965 (3) SA 287 (A).

Rumpff 1978: 100. 
Nationalist purism coupled with the socialising effect of legal education, while De Wet's justification was grounded in, among other things, his liberal philosophy.

Further indicators of De Wet's liberalism in criminal law may be seen in, for example, his rather mischievous comment following a long discussion about sodomy in its various forms and masturbation: "One can only hope that less conservative views as these from 1926 will reign ... We surely do not live in the Middle Ages anymore and the history of Sodom lies even further back." ${ }^{83}$ In a footnote, specifically about male anal sex, De Wet notes: "As to men, we can really get by without this crime." 84

We may also consider De Wet's view on duress in contract law. In Roman-Dutch law, and in South African law, a contract could be cancelled if any person (including third parties) exercised force or made a threat of force against one of the contracting parties. De Wet objected to this view and regarded the English position to be of more value in terms of which a contract may only be cancelled on account of duress if the duress was exercised by one of the contracting parties. ${ }^{85}$ As we know today, the sanctity of contract is regarded as a crucial feature of liberal contract law that regards the autonomy of contracting parties as paramount. ${ }^{86}$

The examples just cited show that there were instances where De Wet used certain provisions of law, regardless of their roots, to promote a liberal conceptualisation of justice. In an Ungerian sense, De Wet used the common law and comparative law as a subtle form of "deviationist doctrine" which is, in rudimentary terms, the use of law to promote subversive political aims ${ }^{87}$ For Unger the subversive aim is probably less classically liberal, but the general tenor of his idea stands strong in De Wet's work: A provision of law had to be critiqued if it fell short of liberal standards. Even though De Wet started writing some thirty years before the naissance of critical legal studies, his exciting, critical and humorous writing style can be regarded as being a primeval form of "deconstruction" and "trashing". ${ }^{88}$ Perhaps for De Wet, one could argue, his call for a stronger systematisation of law was intrinsically linked to his "Enlightened" philosophy. Of course, I by no means suggest that De Wet was fully articulate about his deviationist approach to law and consequently there could be aspects of his jurisprudence that point in other directions.

Even though De Wet believed in liberal principles, he has been criticised for being less radical in his line of attack against the nationalist Apartheid government. There is no evidence that he lashed out against the regressive ways in which Apartheid legislation effectively allowed kidnapping, torture and murder to flourish. However, as Johan Froneman speculates (correctly, I think), De Wet probably thought it best to

83 De Wet 1985: 285. My own translation from the Afrikaans.

84 Idem at $285 \mathrm{fn} 81$. My own translation from the Afrikaans.

85 See De Wet \& Van Wyk 1978: 43ff. This examples observed by Van Blerk 1982: 374.

86 See, eg, Barkuizen v Napier 2007 (5) 323 (CC) at par 57.

87 Unger 1983: 576ff.

88 See a similar acknowledgement (although not with reference to CLS) by Cameron 1993: 59ff. 
avoid criminal charges for supporting the revolution by conserving a great deal of his privilege as a well-off white man in Apartheid South Africa. Instead, he intended to bring about subtle but important changes in the ways that lawyers and, through their work, society operated. Thus, De Wet should not be labelled as a radical Afrikaner. But the labels "critical" and "liberal" Afrikaner would be appropriate. ${ }^{89}$

Furthermore, it must be borne in mind that De Wet completed a doctoral thesis at the University of Leiden in the Netherlands..$^{90}$ The socialising effect of his academic training there should not be overlooked. We might conclude that De Wet's jurisprudence was the combined result of his liberal politics, academic socialisation and possibly other unknown factors that have not received as much attention as the former two. In summary I would regard it incorrect to say that De Wet's purism was simply an apolitical call for science and system. It would be equally wrong to say that his purism was inspired by Afrikaner nationalist politics. Thus, even though his jurisprudence was influenced by the socio-political circumstances of the time, his concern for individual liberty and autonomy in his approach to law shows that he was, in his own modest way, fighting those circumstances rather than keeping them alive.

\section{The near-death of classical purism}

There are two paramount principles to be drawn from the preceding discussions about LC Steyn and JC de Wet. Firstly, classical purism did not have a uniform political inspiration. For Steyn purism was a way to live out Nationalist politics in law, while De Wet saw it as a strategic conceptual tool that could subtly introduce liberal values into the law. I admit that there could have been more political motivations for the purist movement that are yet to be discovered and explored. Secondly, regardless of the various possible political stimuli of classical purism, the role of purist legal education on the minds of lawyers of the time should not be underestimated. To conclude the discussion on Steyn and De Wet, there is a final point that should once again be emphasised. Even if we did not have enough evidence to show that the purist strategies of Steyn and De Wet were personally political, their purism can be said to have had political manifestations. In other words, having actively supported classical purism against the social, cultural, economic and political backdrop of time had political effects. A failure to properly disclose one's political aim(s) in adhering to classical purism during the time of De Wet and Steyn therefore would have had the unfortunate and unintended effect of symbolically promoting Nationalism. Perhaps De Wet could have been clearer about his political stance but luckily for him he left enough jurisprudential breadcrumbs for us to trace his true inspiration back home.

89 Froneman 2014: 478.

90 De Wet was awarded two doctorates in law. The first at the University of Stellenbosch (De Wet 1939) and a second for a monograph (De Wet 1940) at the University of Leiden. 
Be that as it may, classical purism did not thrive indefinitely. By the 1980s the zeal for the movement started waning. The reasons for this decline could have been multifaceted. Some may argue that the objectives of the classical purist movement was met because in many material ways the purists succeeded in making the South African common law more puristically Roman-Dutch. For that reason, purist energy could afford to lose momentum. Others may argue that purism came to an end because bigger and more important issues arose in 1980s when the legal fraternity's opposition to Apartheid grew, and so the focus shifted from what the common law was to what public law had to do. ${ }^{11}$ Supplementary reasons could have included the rise of modern comparative approaches to law that diluted the importance of RomanDutch purity, together with the growing acceptance that the South African common law encapsulated the entire European ius commune and not just Roman-Dutch law. That is not to say that classical purism completely died. There certainly were and still are scholars who take the plight for purifying the common law from English authorities seriously, but those scholars have not received as much popular attention as classical purists once did. To abridge, classical purism was on its deathbed in the $1980 \mathrm{~s} .{ }^{92}$ But, in an unexpected turn of events, purism was resuscitated, revitalised and given new spirit. It now took on a contemporary form.

\section{Contemporary common-law purism}

\section{The historical backdrop}

From the preceding discussion we know that colonisation and Apartheid created manifold serious problems for South Africa. The problems flowing from colonisation and Apartheid can be grounded in what Sampie Terreblanche has called the common theme of triadic oppression. Firstly, colonial and apartheid powers claimed political superiority over Africans. Secondly, the forces economically disempowered the African people by taking their land and natural resources. Thirdly, African people and imported slaves were enchained in various forms of unfree work to the benefit of white masters. At the core of these themes of colonial and Apartheid oppression are claims to political, economic, social and intellectual supremacy. In terms of the sources of South African law these claims to supremacy relegated African law to a position where it remained largely underdeveloped and disrespected and, furthermore, it created a climate in which classical purist notions of the law could flourish. The problem of Afrikaner (and more broadly, white) supremacy was however resisted in various forms. The politics of different resistance movements must be understood to appreciate competing approaches to the introduction of human rights in South

91 Du Bois 2004: 226.

92 Van Zyl 1971: 492. 
Africa, which will in turn also give a greater appreciation for the various approaches to the infiltration of human rights into South African private law.

Early on there was Mahatma Gandhi's passive resistance movement against pass laws. ${ }^{93}$ The African National Congress (ANC) also employed passive resistance techniques at first - famously portrayed in the Defiance Campaign of 1951-1952 - and its resistance was grounded in the civil rights tradition with its commitment to non-racialism as is prevalent from reading the Freedom Charter of $1955 .{ }^{94}$ The ANC's commitment to non-racialism arguably arose from the presence of white communists amongst the ANC's allies. ${ }^{95}$ By 1959, dissidents broke free from the ANC to form the Pan Africanist Congress of Azania (PAC). The PAC was formed as a rejection of a number of aspects about the ANC's philosophy including the "Christian liberal tradition" that promoted non-violence, the idea that true African liberation could be achieved with the assistance of white people, and the absorption of European ideologies (such as communism) that displaced the prominence of black nationalist thought. ${ }^{96}$ The PAC became a militant organisation that was sceptical about the Freedom Charter's potential to disrupt white power in its various forms. ${ }^{97}$ In 1960 both the PAC and the ANC were banned, which resulted in both organisations introducing strategic militarisation. In 1961 the military wing of the PAC called Poqo was formed (that would later be replaced by the Azanian People's Liberation Army, APLA), and in 1962 the ANC's Umkhonto we Siswe (MK) took up the armed struggle against apartheid. ${ }^{98}$ Effectively South Africa was on a knife's edge to falling into full-blown civil war.

Let us fast forward to the 1980s. By this time many lives had been lost and there was no clear prospect of one party finally triumphing over the other. Furthermore, the NP government was facing severe sanctions from the West to end Apartheid. Those sanctions put the NP rule in such a precarious situation that, even if it did not really want to, it simply had to heed the call for the introduction of human rights in South Africa. ${ }^{99}$ On the other hand, the ANC came to realise that it needed broader

93 See, eg, Gandhi 1961.

94 This commitment is evidenced by phrases like these in the Freedom Charter: "The rights of the people shall be the same, regardless of race, colour or sex"; "There shall be equal status in the bodies of state, in the courts and in the schools for all national groups and races"; "All people shall have equal right to use their own languages, and to develop their own folk culture and customs"; "All national groups shall be protected by law against insults to their race and national pride"; "The preaching and practice of national, race or colour discrimination and contempt shall be a punishable crime"; "All shall be equal before the law; "All shall enjoy equal human rights"; "Men and women of all races shall receive equal pay for equal work"; and "Peace and friendship amongst all our people shall be secured by upholding the equal rights, opportunities and status of all".

95 See eg Kondlo 2009: 53.

96 Idem 54.

97 Idem 57.

98 See, eg, Bophela 2005; Cherry 2011; and Simpson 2016.

99 Woolman \& Swanepoel 2014: 35. 
political support from the international community (and not just from the far left) if it wanted to succeed as a legitimate government after formal apartheid would end. ${ }^{100}$ By 1988 the ANC published its Constitutional Guidelines for a Democratic South Africa in which it committed itself to constitutionalism and a Bill of Rights. ${ }^{101}$ In 1990 Nelson Mandela was released and various liberation organisations were unbanned. ${ }^{102}$ By 1991 the NP instructed the South African Law Commission to draft a report on the possibility and promise of human rights. ${ }^{103}$ The NP conducted a referendum in 1992 asking white South Africans to vote on whether negotiations should have been initiated with the ANC. Indeed, they voted that negotiations had to start.

Both the ANC and NP showed the clear intention to support a peaceful, negotiated transition grounded in human rights and, in principle, violence was conditionally suspended from both sides. As the evidence collected by the Interim Report on Group and Human Rights showed, "[t]here is almost universal acceptance and insistence that human rights should be recognised and respected in this country as rights or interests that merit protection". ${ }^{104}$ Joining the ANC and NP's appeal to human rights and constitutionalism was, among others, the Democratic Party, ${ }^{105}$ the predominantly Indian party called Solidarity (not to be confused with the trade union Solidariteit today), ${ }^{106}$ the predominantly coloured Labour Party, ${ }^{107}$ the Inkhata Freedom Party, ${ }^{108}$ and the Government of KaNgwane. ${ }^{109}$ Even though the South African Communist Party (SACP) was invited to make submissions to the Commission on human rights, it did not respond but was an ostensible ally of the ANC. ${ }^{110}$ Additionally, the majority of religious associations in South Africa supported the idea of a Bill of Rights for South Africa. ${ }^{111}$ There were however three main groups of objectors to the popular opinion. The far-left, in the form of the PAC, the far-right, in the form of various

100 Idem 35.

101 Idem 35-36.

102 Idem 35.

103 Idem 35-36.

104 South African Law Commission 1991: 6.

105 Idem 147.

106 Idem 148.

107 Idem 149.

108 Idem 167.

109 Idem 162.

110 Idem 167.

111 The Interim Report notes that religious associations that supported human rights included the Nederduits Gereformeerde (NG) Kerk which originally also supported apartheid (205); the Apostolic Faith Mission (221ff); the Methodist Church (222ff); the Roman Catholic Church (225); churches affiliated with the Church of England (225ff); the Presbyterian Church (227ff); the Baptist Union of South Africa (228ff); the Jewish Board of Deputies (232ff); and the Islamic Council (233ff). Conflicting views were presented by the ranks of the Reformed Churches in South Africa (209ff), and various charismatic churches (229ff). The Zion Christian Church did not respond to the request for comment because the church discourages political involvement of its members (233ff). 
Afrikaner supremacist organisations, and some religious alliances were less excited about the introduction of human rights.

While the ANC and NP were reflecting on the potential of peaceful transition, the PAC was still demanding war. In an excellent account of PAC history, Kwandiwe Kondlo notes that the organisation preferred violence over negotiations because the latter would be ineffective in restoring land to African people and securing their right to self-determination. ${ }^{112}$ In other words, negotiations with white people who held the land and other forms of power ran the risk of allowing the privileged few to maintain their systemic advantage. Furthermore, the likelihood of securing African sovereignty without neo-colonial interferences decreased as the proclivity for negotiation with an empowered white minority increased. The persistent call for violence is probably what caused the PAC's popularity and power to wane during the period of democratic transition where the international community and the majority of South Africans championed a non-violent dedication to human rights negotiations. ${ }^{113}$ The PAC was, however, not the only organisation against the idea of peaceful transition and the introduction of human rights in South Africa.

The South African right wing was also loath to accept the notion of human rights. The Conservative Party (CP), which was even more fundamentalist than the NP, denied the necessity of a Bill of Rights because it would have been "superfluous"; it would have introduced equality (which was said to be a "leftist" political ideology compared to the "neutral" policy of Apartheid); it would impose communism on the entire nation by securing socio-economic rights; it would politicise judges who would be required to interpret a leftist constitution compared to the "neutral" one in place; and the sovereignty would vest in a document and not in the majority of South Africans who were apparently white. ${ }^{114}$ The Herstigte Nasionale Party followed the $\mathrm{CP}$ declaring that human rights are "anarchist" and "communist" in nature, and that they would result in the flourishing of "terrorism". ${ }^{115}$ The conceptual conflation of communism, liberalism and terrorism (that we know today are different notions) probably came about because all three concepts were grouped together as a threat to white minority rule. There were a few right-wing individuals who also made submissions to the Commission on Human Rights, making obscure arguments about why Apartheid had to stay and why white supremacy was important for the prosperity of South Africa. ${ }^{116}$ The Afrikaner Weerstandsbeweging (AWB) was so adamant about the entitlement of the Afrikaners to secede from South Africa that it practically expressed no opinion about the introduction of human rights in principle. ${ }^{117}$ The Afrikaner Volkswag and the Boere Vryheidsbeweging added a further dimension

112 Kondlo 2009: 261.

113 Idem 258-259.

114 South African Law Commission 1991: 145ff.

115 Idem 152ff.

116 Idem $171 \mathrm{ff}$.

117 Idem 162. 
to the rejection of human rights by emphasising how human rights deified man and defied God - while Apartheid laws apparently did not. ${ }^{118}$

In a similar vein various religious institutions also objected to the notion of human rights for South Africa. The Afrikaanse Protestante Kerk (APK) was a splinter group from the NG Kerk that broke away when the NG Kerk declared that it would no longer support Apartheid. Unsurprisingly the APK rejected the notion of a Bill of Rights because it was godless and they could not accept a prohibition of unfair discrimination that was purportedly, for them, sanctioned by their God. ${ }^{119}$ The Nederduitsch Hervormde Kerk emphasised that humans have no rights but only privileges and that an integrated society would be unacceptable in the eyes of their God. ${ }^{120}$ The Christian organisation Vereniging Bybel en Volk rejected human rights because they were too "humanistic". ${ }^{121}$ These religious organisations might be categorised under the umbrella term of right-wing religious associations.

Despite all the conflicting opinions about the question of whether South Africa needed a bill of rights, the majority opinion (effectively comprising of the ANC, $\mathrm{NP}$ and its supporters and allies) prevailed. The legs of the peaceful negotiation table were made from human rights and constitutionalism - the real matters that had to be discussed revolved around what the content of the new Constitution would be. It comes as no surprise that during the Congress for a Democratic South Africa (CODESA) and the Multi-Party Negotiation Forum the ANC and the NP took on prominent roles. Various debates took place about issues of secessionism, federalism, and the exact content of the Constitution, but the core of the compromise reached between various stakeholders was that a five-year transitional government would be democratically elected to finalise a new Constitution for South Africa. ${ }^{122}$ The term "compromise" used here is important. Right-wing organisations refused to meet anyone else halfway and even unsuccessfully tried to derail the negotiation process. Similarly, the PAC was concerned that the process of reaching a compromise would create an elite class of persons that excluded exploited African labourers. ${ }^{123} \mathrm{~A}$ faction of PAC strategists later realised that even though they disagreed with the process of negotiation that they had to make their voice heard at the negotiation table. ${ }^{124}$ It was thanks to the mediation of the government of Zimbabwe that the PAC's military wing APLA and the NP government could reach a ceasefire during the time of negotiation. Eventually thirty four constitutional principles were agreed upon by the various stakeholders that ensured power-sharing between them. The so-called "final"

118 Idem 155-161.

119 Idem $215 \mathrm{ff}$.

120 Idem 219ff.

121 Idem 235ff.

122 Woolman \& Swanepoel 2014: 38.

123 Kondlo 2009: 263.

124 Idem 267. 
Constitution had to be squared with the thirty four constitutional principles that were laid down in the "interim" Constitution of 1993, by the Constitutional Court. ${ }^{125}$ From here the first truly democratic elections were held on 27 April 1994 and in due course the newly elected parliament of South Africa sat as the Constitutional Assembly to pass the Constitution of the Republic of South Africa, 1996. That Constitution was finally certified by the Constitutional Court in December of $1996,{ }^{126}$ signed by President Nelson Mandela shortly after that, and took effect on 4 February 1997.

The opinions of different scholars on the place and purpose of human rights in private law must be understood to have been formed in the arena of the socio-political debates about human rights that were prominent during the period of democratic transition in South Africa. Similar to how the political climate of the time allowed for the flourishing of classical purism, the political debates surrounding the introduction of the Bill of Rights influenced the stances that people would take to its impact on the common law.

As noted in the introduction to this piece, my focus in the discussion of contemporary purism will be on delict scholarship. In $\S 32$, I will pay attention to the early and later work of professors Johann Neethling, Johan Potgieter and Hans Visser, who will go down in history as some of the most influential delict authors of our time. The trio authored the famous textbook entitled Deliktereg in 1989, which has since been translated as Neethling-Potgieter-Visser Law of Delict and has seen its sixth and seventh editions published after Visser's passing. I consider their work in particular because each of the three scholars has published prolifically about the theory of the interaction between private law and human rights during the time of democratic transition and thereafter, and it might focus our attention on more conservative arguments pertaining to the rejection of human rights in private law. In $\S 33$, I turn to outline the work of scholars who have been arguing against models of strong constitutional application to private law, but from a more progressive or even radical perspective. I will, firstly, consider the recent thinking of a former South African delict academic and legal philosopher (who today works on legal theory in Luxembourg), Professor Johan van der Walt, as it relates to the issue at hand. I survey his most recent work because it is in my view the most politically candid comparative and in-depth theoretical work on human rights in private law. I further provide some tentative reflections on what we might call the decolonial thought of Professor Mogobe Ramose whose anti-constitutionalism has featured more prominently in recent times. The thinking of Professor Anton Fagan, whom I regard as one of the most provocative and important delict scholars in South Africa

125 Woolman \& Swanepoel 2014: 37-38.

126 The first unsuccessful attempt at certification is recorded as Certification of the Constitution of the Republic of South Africa, 19961996 (4) SA 744 (CC). After further amendment, the Constitution was successfully certified in Certification of the Amended Text of the Constitution of South Africa, 19961997 (2) SA 97 (CC). 
today, is discussed in $\S 4$ together with an invitation that is extended to the broader community of delict and private law academics. I consider these scholars' works to try to provide support for my claims about critical legal realism.

\section{Contemporary purism as conservative sentiment}

Even though Neethling, Potgieter and Visser have written a textbook in which they ostensibly speak with a unified voice on the issue of human rights in delict, their respective scholarship before the first edition of the textbook perhaps shows different nuances in their respective viewpoints.

In 1971 Neethling wrote a thought-provoking article about the juridical nature of human rights. ${ }^{127}$ His view was that even though human rights had not been constitutionally entrenched in South Africa at that time, the common law afforded a great deal of protection to human rights. For Neethling, the protection of human rights was a private-law issue because they served to protect the individual. Human rights featured in private law either as presumptions of public freedom (for example the presumption in favour of free speech), subjective rights (where the rights in question have some type of economic value), or capacities (where the rights in question have no economic value). On the other hand, the protection of community interests fell in the domain of public law and comprised of, among other things, the limitation of human rights. ${ }^{128}$ These central points of Neethling's argument are striking because he indirectly acknowledges that human rights and the common law are at least reconcilable, at best that the two disciplines cannot necessarily be divorced from one another. Even though the scope of Neethling's article did not allow him to delve into whether unrestrained limitations of human rights should be tolerated, as was the case in South Africa, it seems that he was, in principle, not in a severe state of anxiety about the relationship between human rights and the common law.

By 1989 Potgieter's views on human rights came to the fore. ${ }^{129}$ His prime concern was that human rights could not be justified on the basis that they were Christian, contrary to what many churches and their followers believed during the time of democratic negotiation and transition in South Africa. ${ }^{130}$ Firstly, Potgieter contended that human rights originated from humanist philosophy and not the Bible. ${ }^{131}$ Secondly, Potgieter said that natural man reflects the image of Satan (and not of God) because of man's sinful nature before his acceptance of Jesus as saviour. ${ }^{132}$ Thus, because all humans are inherently evil, Potgieter contended that people do not deserve protection as the human-rights ideology suggests. To the contrary, the evil

127 Neethling 1971.

128 Idem 243ff.

129 Potgieter 1989.

130 Idem 387.

131 Idem 393.

132 Idem 395-396. 
inherent in human beings requires severe limitations of rights. ${ }^{133}$ The "unwarranted suspicion of the country's legal system and security forces" and the "general spirit of opposition against any form of authority" were products of the "exaggerated obsession with the freedom of man" who is erroneously presumed to be inherently good under the human-rights paradigm. ${ }^{134}$ Thirdly, with reference to various biblical texts, Potgieter suggested that especially the rights to bodily integrity and life cannot be secured for Christians because humiliation, persecution, oppression and death are part and parcel of what they must endure. ${ }^{135}$ Fourthly, human rights are associated with uprisings against the state that are not sanctioned by Jesus who is said to have suffered at the hands of government but accepted his fate. ${ }^{136}$ Jesus's love was self-sacrificing and he never requested equal rights for anyone else. ${ }^{137}$ Finally, for Potgieter, unequal treatment of people did not constitute injustice - true injustice results from crime, violence, adultery, broken families, child molestation, corruption and other evils that human rights would never be able to cure. ${ }^{138}$

There can be no doubt that the Black population (by that I include Coloured, Indian and Asian people) in South Africa suffered the most under Apartheid laws that aimed to criminalise their mere being, even though many white citizens also found themselves in conflict with the legal system for their conscience, belief, feelings and/ or deeds. Thus, even though Potgieter targeted the human race as a whole when he painted the picture of the natural human as an incarnate devil, we could argue that his call for the endurance of suffering, his support expressed for strong policing, the plea for the silent acceptance of authority, and his downplaying of inequality as injustice, are all effectively parts of an offensive telegram posted to Black South Africa: Accept your fate as an inferior and oppressed people because it is what Jesus would have done. His view on human rights expressly fell into the conservative camp within the Reformed Churches in South Africa. ${ }^{139}$

If Potgieter had made it clear in his arguments that he opposed both Apartheid and human rights from a Christian perspective and that both systems should have been substituted with a pure commitment to love and the humane treatment of people, we could have concluded that his rejection of human rights was not necessarily conservative or right-wing. Unfortunately, his implicit support for Apartheid ideology taints his purportedly "neutral" Christian rejection of human rights with conservative political sentiment. This is also the gist of Lourens du Plessis's response to Potgieter's legal theology. ${ }^{140}$

133 Idem 399.

134 Idem 400. My own translation from the Afrikaans.

135 Idem 398 \& 401.

136 Idem 401.

137 Idem 403.

138 Idem 404-405.

139 South African Law Commission 1991: 209ff \& 243ff.

140 Du Plessis 1990. 
Du Plessis retorted with two strategic attacks. Firstly, Du Plessis explained that the Bible does not have to say expressly that it supports human rights for that to be the case, and even if human rights had humanist origins it could nevertheless be reconciled with biblical teachings. Thus, one could read human rights and the Bible separately and conclude that the two are harmonious. ${ }^{141}$ Du Plessis's second strategy was to show how various biblical texts existed that prove Potgieter's comments to be questionable. For example, Potgieter made no reference to Jesus's most important command that even many non-Christians can find agreeable: Love your neighbour as yourself. ${ }^{142}$ Potgieter's comments are in no way compatible with that command. According to Du Plessis, biblical exegesis always required contextual understanding, which was missing in Potgieter's work. ${ }^{143}$ For Du Plessis, Potgieter read the Bible from a particular "paradigmatic orientation", just like everyone else, ${ }^{144}$ and that his understanding of the Bible was unavoidably influenced by his "hardly-disguised political presuppositions and prejudices". ${ }^{145}$

Potgieter's approach was described by Du Plessis as being "right-wing reactionary status quo theology" because it is filled with a pre-determined commitment to a rejection of human rights on account of a fear of socio-economic transformation to the potential detriment of the privileged minority of white South Africans. ${ }^{146} \mathrm{Du}$ Plessis concluded his response to Potgieter, significantly for present purposes, by saying that a "good way to stop the cry of reactionary theology is to be honest about one's own paradigmatic contextualised engagement with the Bible". ${ }^{147}$ Similar to what Du Plessis had to say about Potgieter's reading of the Bible, I caution that we must be honest about our own paradigmatic and contextualised engagement with the common law on the issue of purism.

Potgieter replied to Du Plessis in the same year. ${ }^{148}$ In addition to the technical arguments about what the Bible should be understood to mean, Potgieter this time appeared to have shown a more balanced distrust towards human rights. He rubbished the claim that the Bible supported Apartheid just as much as the claim that it could support human rights. He contended that his concern was simply about what a plain reading of the Bible said about human rights. ${ }^{149}$ To prove that he was not entering the political arena, he indicated that human rights could hold some positives such as the end of the abuse of state power, the responsible use of individual freedom, the promotion of "civilised standards", and "stability, law and order" in the time of

141 Idem 409.

142 Idem 408.

143 Idem 406.

144 Idem 409.

145 Idem 410.

146 Idem 411-412.

147 Idem 412. My own translation from the Afrikaans.

148 Potgieter 1990.

149 Idem 413. 
transition. ${ }^{150}$ At first glance, it would not be unfair to suggest that Potgieter appears to have reneged on his earlier position to some extent (even though the phrase "civilised standards" leaves one questioning who the "uncivilised" folk were in his eyes). However, his restrained support for human rights during this time can be treated with cynicism.

Due to the fact that the introduction of human rights in South Africa was imminent and seemed inescapable, the concern of Potgieter's work turned from a complete rebuff of human rights to a call for objectivity during the transition period so that all persons would be protected by human rights. ${ }^{151}$ He would moderately and tentatively support the general idea of human rights in a new Constitution as long as it was drafted and implemented in a politically objective way. In his view "[1]aw must now shed the shackles of political domination", ${ }^{152}$ and so jurists who would be tasked with drafting the new Constitution and its Bill of Rights had to do so with "scientific care" in a way that refrained from falling into right-wing or leftist camps; human rights thus had to be "ideology neutral" for the new South Africa. ${ }^{153}$ This was indeed a strange imploration. I do not deny that, for example, the legal technicalities associated with whether a cheque has two or three lines drawn across it are of little political importance. But it seems impossible to adopt a Bill of Rights after an authoritarian, white-supremacist regime and label that process as neutral, regardless of what the content of the rights would be. The very act of admitting that the status quo of the time was problematic was an inescapably political deed, just as it would have been a political act to demand the maintenance of Apartheid. If Potgieter's request was aimed at finding a midway between the far right and the far left, that request would also have been manifestly political and a green light to the ideology of centrism. That aside, Potgieter himself fell short of his petition for political neutrality. In the same piece in which he advised neutrality, he described the "liberal-Western" approach to human rights as a catalyst for "increased crime, spiritual bankruptcy and moral decay". Additionally, he noted with concern that "most" South Africans of the time were allegedly (I must emphasise, allegedly) conservative and that an imposition of a non-conservative law on them would be a great injustice. ${ }^{154}$ This is not the type of argument that I would describe as politically dispassionate.

The 1993 Constitution entered the scene and so Visser teamed up with Potgieter to provide some critical comments on the Bill of Rights. ${ }^{155}$ In that piece the professors emphasised the need for a "proper" Bill of Rights, but nevertheless approached the 1993 Constitution with circumspection. They were "doubtful" as to whether the Bill

150 Idem 422. My own translation from the Afrikaans.

151 Potgieter 1991.

152 Idem 802.

153 Idem 803.

154 Idem 806.

155 Visser \& Potgieter 1994. 
of Rights would be able to save South Africa from "unsophisticated" political views of the majority of South Africans, the lack of experience of the new government, the criminal records of various new government officials, and suspect political agendas of some political parties. ${ }^{156}$ In addition to these problems, it seems that their angst about human rights was also premised on the fact that the 1993 Constitution would open the door for the flourishing of sodomy, ${ }^{157}$ Satanism, sex shops, suicide, scandalous textual interpretation, and an array of other "evils" not necessarily starting with the letter "s". ${ }^{158}$ Even though the implicit call in the paper of Visser and Potgieter was for a politically neutral (read: conservative) Bill of Rights, there is a rotation back to an anti-human rights sentiment during this time.

In the same volume Neethling and Potgieter collaborated on a discussion about a defamation decision and the possible impact of the 1993 Constitution on such cases. ${ }^{159}$ Here a different spirit of argumentation featured in their piece. The claim was not that the Bill of Rights had to be done away with or that human rights were evil; instead Neethling and Potgieter accepted that human rights were probably here to stay and that the question was now what they meant for other areas of law. The essence of Neethling's 1971 description of the juridical nature of human rights was restated: The common law has always protected human rights and thus the new Bill of Rights was not going to disrupt the common law of defamation. The "common law = human rights" model however held its own problems. As Henk Botha observed, Neethling and Potgieter used the model to justify existing common-law rules relating to defamation without being open to the possibility of reimagining those rules in light of constitutional norms. ${ }^{160}$ For them the common law of defamation, which tends to elevate the right to reputation above the right to freedom of speech, struck the perfect balance between the constitutional rights to dignity and freedom of expression, without any further interrogation of alternative possibilities. For example, they were quick to rebuke anyone who argued that freedom of expression should have become more prominent in post-Apartheid (post-censorship) South Africa, and ridiculed those contenders on the basis that they dared question the views of esteemed judges. ${ }^{161}$ Thus, for Botha, Neethling and Potgieter's acceptance of human rights was only nominal acceptance without true appreciation for what the Constitution could have meant for the transformation of private law.

In their next case discussion on defamation law, Neethling and Potgieter ostensibly tried to dispel the notion that they were opposed to the Constitution. ${ }^{162}$

156 Idem 493.

157 See, in this regard, also Visser 1995a: 704-705 where the author also expresses anxiety about "abnormal sexual orientation" receiving too much constitutional protection at the expense "normal" relationships.

158 Visser \& Potgieter 1994: 494-498.

159 Neethling \& Potgieter 1994.

160 Botha 1994.

161 Idem 497.

162 Neethling \& Potgieter 1995. 
They went so far as to accept that constitutional values could enrich the common law of defamation (and this time they were open to the possibility that the common law could change to strike a better balance between the rights to dignity and freedom of expression), but nevertheless cautioned for care and that the Constitution did not demand a radical break from past legal traditions. ${ }^{163}$

Commenting on the same case, Visser had a different view, imbued with human rights anxiety. ${ }^{164}$ This time the alarm about human rights did not stem from its inherent evil nature but that the interpretation of human rights would be unscientific. ${ }^{165}$ Visser argued that the constitutional interpretation exercise would lead to chaos in private law because: (1) judges' political and intellectual baggage are drawn into interpretation; (2) the text of the Constitution was too ambiguous and vague to mean anything in particular; (3) lawyers would now have to be politically conscious and actively promote reconciliatory ideals in law; (4) the reliance on historical context in the interpretation of human rights would invariably be slanted towards addressing the injustice of Apartheid without considering the "general backwardness, lack of discipline, genocide, lawlessness, spiritual darkness etcetera in too many parts of the African continent"; and (5) the interpretation of the Constitution would require delving into the "tedious" deliberations that led to its adoption. ${ }^{166}$

As to his first three contentions, the critical legal realist jurisprudence promoted throughout this discussion would respond by saying that law is always an openended interpretative exercise with rival possibilities that are often informed by a judge's personal make-up. The third to fifth contentions lift the veil covering Visser's politics. Visser's incredulity towards human rights might be phrased as a concern for legal certainty and objectivity, but his refusal to entertain the reconciliatory ideal of the Constitution coupled with his snide remarks aimed at African people is starkly "reminiscent of the "old order", ${ }^{167}$ to say the least. A more subtly phrased attempt would have been necessary to convince us as readers of his work that he was writing from a position of political neutrality. Thankfully, for critical legal realists, Visser has provided us with enough evidence to show that his anti-constitutionalism was blatantly reactionary and right-wing political.

After Visser's troubling remarks were responded to by Gretchen Carpenter and Christo Botha, ${ }^{168}$ it appears that his human-rights fears calmed down. Additionally, cases such as Fose v Minister of Safety and Security, ${ }^{169}$ Potgieter v Killian,,${ }^{170}$ and Du Plessis $v$ De Klerk ${ }^{171}$ put Visser at ease that private law was not going to be battered

163 Idem 710. See also Neethling 1997; and Neethling \& Potgieter 1997.

164 Visser 1995b.

165 Idem 747.

166 Idem 748-749.

167 Carpenter \& Botha 1996: 126.

168 Ibid.

1691996 (2) BCLR 232 (W).

1701995 (1) BCLR 1498 (N).

1711996 (3) 850 (CC). 
to a point where it would become unrecognisable. Human rights were not that bad after all and perhaps Neethling and later Potgieter had a point when they said that the common law was largely compatible with human rights. That is not to say that, for Visser, human rights were of fundamental importance because human dignity had to be restored after Apartheid; no, on the contrary, human rights were tolerable because it would not be as unsettling to the common law as initially anticipated and because some German delict scholars told us that human rights are not necessarily detrimental for the development of private law. ${ }^{172}$

Today Neethling and Potgieter's textbook acknowledges that the Constitution could have an effect on private law, but that it should be presumed that the common law is consistent with the Constitution because the contents of the Bill of Rights have historically always been part of our common law. ${ }^{173}$ We might respond to this comment and say that even though the common law certainly did afford protection to various subjective rights that are similar in name to those rights protected in the Constitution, the latter rights are arguably more expansive than the subjective rights recognised at common law. The right to bodily integrity and freedom, for example, was recognised in Dutch law at the time of South Africa's colonisation. However, slavery was a legitimate practice of the Dutch for many years after colonisation. It is therefore not unimaginable that the spirit of certain constitutional rights could be different to that of common-law rights and therefore one should be cautious to always have as starting point that the common law is robotically constitutionally compliant. Why this obsession with keeping the common law pure?

There is an interesting and as yet unexplored textual psychological analysis to be made about contemporary common-law purism. Sigmund Freud taught that the unconscious is that part of the mind where we push painful desires, fears, needs and conflicts that are unresolved within ourselves. ${ }^{174}$ The process of pushing the painful experiences from our consciousness to the realm of the unconscious occurs through the use of various defences or coping mechanisms. There is, for example, selective perception, selective memory, denial, displacement, projection and regression. Yet, there is also the coping mechanism of avoidance. Avoidance is the process by which traumatic experiences, conversations about those experiences, or resurgences of those experiences are evaded. ${ }^{175}$

Let us apply this elementary exposition of Freud's theory to the situation at hand as an attempt to hypothesise at least one underlying reason for the contemporary purism in Neethling, Potgieter and Visser's textbook. The transition period in South Africa that led to the constitutional drafting process involved an ideological

172 See Visser 1996a; Visser 1996b; Visser 1997a; Visser 1997b.

173 Neethling \& Potgieter 2015: 18.

174 For a general introduction to psychoanalysis as a critical tool for literary analysis, see Tyson 2006: $11 \mathrm{ff}$.

175 See eg Wegman 1985: 219ff. 
battle. Those who engaged in the battle on fundamental terms, in other words on the question of whether human rights should be introduced in South Africa or not, either won or lost. The eventual introduction of the new Constitutions and their Bills of Rights signalled the defeat of scholars like Potgieter and Visser who were originally apprehensive about human rights. In light of their passionate appeals for the rejection of human rights canvassed above, it is not unreasonable to say that their defeat constituted an academically traumatic experience. One way of coping with the trauma would be to avoid talk about human rights, or at least to avoid the infiltration of human rights into private law that caused so much consternation all those years ago. Thus, when these scholars today effectively say that human rights must be avoided in delict cases (unless if some special circumstances arise), we could say that they are avoiding human rights in the Freudian sense. What was the best way to avoid the trauma while being mindful of the fact that human rights are now the order of the day? The answer is by relying on Neethling's earliest contention that human rights manifest themselves in the common law. In this way a compromise was reached in terms of which the views of Neethling, Potgieter and the late Visser can reside in harmony in one textbook, speaking with one voice on the issue of human rights in delict. In this way, the scholars could keep the common law pure, while admitting that human rights exist in modern South Africa, but without having to rejoice about the transformative promise of the Constitution. Even if one is not convinced by this psychoanalytic move on my part, at the very least, the position of the professors on human rights in private law has a manifest conservative political verve, even if their original political beliefs have in fact since changed, for the simple fact that they have not expressly recanted their earlier views. Professor Neethling might be the only one of the trio on whom it is difficult to impose right-wing political motives - with that said he was reticent in serious debates during the period of transition which was a time when his voice could have brought moderation and calm. However, as will be revealed in the next section, contemporary common-law purism can be informed by a radically different political commitment.

\section{Contemporary purism as leftist scepticism}

Not all contemporary common-law purism is necessarily conservative. This is what Johan van der Walt writes in his most recent book, The Horizontal Effect Revolution and the Question of Sovereignty, on the interaction between human rights and private law. ${ }^{176}$ As a point of departure, it should be emphasised that Van der Walt is not passionately against the idea of constitutionalism or even the broad idea of constitutional application to private law. However, he is concerned about the fact that models advocating strong constitutional rights application have two potentially calamitous effects. On the one hand, overzealous constitutional application to the 
private sphere could serve to crush value pluralism. On the other hand, even though we might expect constitutional rights to influence private law in ways that churn out progressive results, this is not an inexorable reality. These two points of concern proffered by Van der Walt require further explanation and reflection.

Many South African legal scholars have been enthusiastic about the Constitutional Court's remark in Carmichele v Minister of Safety and Security $y^{177}$ that "[o]ur Constitution is not merely a formal document regulating public power. It also embodies, like the German Constitution, an objective, normative value system". ${ }^{178}$ However, Van der Walt contends that we should be cautious about " juristocratic' impositions of substantive constitutional values on walks of life that do not call for them." 179 Even though the private is sometimes political, it is not always political according to Van der Walt. ${ }^{180}$ For him the only time that the private becomes political, and therefore constitutional rights become relevant for the private sphere, is when a dispute raises a social majority-minority tension. For example, the question of same-sex marriage is such an issue - the implications of a dispute about who can get married strikes at a social tension between a specific majority (heterosexuals) and minority (homosexuals). Constitutional rights play into such a dispute because a liberal democratic constitution has an important function to fulfil in the mediation of majority-minority relations. If a dispute arises about how many days a person should have to lodge an insurance claim, that dispute does not raise an issue of social importance between a majority and minority. Thus, there are disputes that are de minimis non curat lex constitutionis and have trivial constitutional importance. Such disputes, which are most disputes according to Van der Walt, should not involve the invocation of constitutional rights because it would impinge on individual liberty unnecessarily by forcing an objective, normative value system onto every aspect of human existence. That, in turn, does not promote normative relativism and pluralism. ${ }^{181}$

Even if we were to accept for a moment that constitutional rights could and should form a normative value system that regulates our most private dealings with others, Van der Walt warns that constitutional rights do not always result in progressive, social justice compliant judgments. ${ }^{182}$ In a string of cases the European Court of Justice has recently been faced with trying to strike a balance between the right to social security on the one hand and the right to economic freedom on the other hand. ${ }^{183}$ In those cases, says Van der Walt, the Court acted conservatively

177 Carmichele v Minister of Safety and Security 2001 (4) SA 938 (CC).

178 Idem par 54.

179 Van der Walt 2014: 30.

180 Idem 22.

181 Idem 16.

182 Idem 7.

183 See Laval EU: Case C-341/05 [2007], Viking EU: Case C-438/05 [2007], Luxembourg EU: Case C-319/06 [2008], and Rüffert EU: Case C-346/06 [2008]. Discussed in more detail in ch 7 of Van der Walt 2014. 
in favour of the interests of the rich and powerful which effectively eroded the progressive political project of social reform in Europe. Thus, Van der Walt argues that the horizontal application of human rights has not brought about the egalitarian revolution in Europe that might have been hoped for. The task of bringing about more serious social reforms probably lies in the hands of social movements and electoral politics, and it appears that the constitutionalisation of private law could actually do more harm than good for the realisation of egalitarian dreams. ${ }^{184}$

It should be clear from the above exposition that Van der Walt is writing neither from the right-wing camp, nor the libertarian faction of constitutional-common-law adversaries. It appears that his apprehension towards human rights in the private sphere is legitimately rooted in an egalitarian, liberal democratic approach to constitutionalism. Hidden in his problematisation of the current trend of the eager constitutionalisation of private law is an argument that reminds us of the limits of law - perhaps many people have been so enthusiastic about the possibility of human rights shaking up the politics of private law that they have forgotten that human rights are not perfect legal mechanisms that can magically take away all of a society's problems. In fact, just like the endurance of the common law has been criticised for being a project of ongoing colonial domination, the South African Constitution has also been decried as a neo-colonial assignment used by the West to dominate Africa.

Professor Mogobe Ramose has been one of the foremost African philosophers who have taken issue with the constitutional veneration that is observed in South Africa today. He notes that

the transition to the 'new' South Africa did not restore full, integral, comprehensive and unencumbered sovereignty to the indigenous peoples conquered in the unjust wars of colonisation. Only limping defective sovereignty was conceded by the successors in title to the 'right of conquest'. Thus the much acclaimed 'miracle' of change in South Africa is a basic source of concern, since it set aside the basic question of substantive historical justice in the name of compromise. Compromise without justice is blind and empty. But justice without compromise is a recipe for future contestations. It is precisely the formal vacuous justice conceded to the indigenous conquered peoples of South Africa which is today the reason for the contestations that prevail in the country. ${ }^{185}$

For Ramose, justice will only be realised if full and substantive African sovereignty is restored. One might think that this is a peculiar view to hold; after all, a Black government is in power and all people are afforded human rights in terms of the Constitution. However, there are three main reasons why Ramose believes that true African sovereignty has not been restored to the conquered people of South Africa.

Firstly, the current constitutional dispensation in South Africa makes a mockery out of former African kingdoms by recognising "traditional leaders" but effectively affording them no genuine political or legal authority over their territories - a problem

184 Van der Walt 2014: 9.

185 Ramose 2007: 319. 
intensified by the fact that most land in South Africa still belongs to the white minority. Thus, territorial sovereignty does not truly vest in Africans. ${ }^{186}$ Secondly, customary law (which should really be called African law) is subject to constitutional scrutiny (which is a cornerstone principle of European law), which means that European domination persists in the realm of legal epistemology in the "new" South Africa. ${ }^{187}$ Thirdly, even if Africans decide to pass new laws in an attempt to decolonise their condition (which is their popular democratic entitlement to do) their attempts are subject to testing against a Eurocentric document that proclaims itself to be supreme. As a result, sovereignty in South Africa still, to all intents and purposes, vests in Europe and not in the African people. ${ }^{188}$

At first glance one might see an overlap between the early thinking of Potgieter and Visser and the current thought of Ramose. Indeed, both sets of views are manifestly anti-constitutional. But the snag is that the political spirit underlying the two forms of anti-constitutionalism are very different and are divided between the far right and the far left of the ideological spectrum. There is another weighty difference between the views of the delict scholars and Ramose.

Ramose's decolonial vision for South African law does not amount to commonlaw purism. If I understand Ramose correctly, he would reject both the common law and the Constitution as sources of law in the process of decolonising South African law. Ramose's theory would reject labelling the South African common law as both "South African" and "common". His theory would categorise the common law as conquestuous European law that is not shared in "common" by all people who find themselves living in the locus that is South Africa. It is true that the original European law brought to South Africa has mutated into a body of rules with its own shape and form, but that law was developed for and by Europeans incidentally living in South Africa (even if those Europeans might have called themselves "South Africans"). Ultimately the economic and political spirit of the European law is so different to African law that we should be slow to conflate the two systems. Therefore, decolonial anti-constitutionalism does not amount to common-law purism in any way and, true to its origins, the "decolonial option" will not resemble the current dominant forms of "South African" law in any way. ${ }^{189}$

To conclude this section on contemporary common-law purism, it must once again be emphasised that common-law purity can be underscored by different political commitments - from the far right to the left. However, even if one's common-law purism is inspired by progressive political aims, it lacks the frank realisation that a decolonial reimagination of the law will not take place under the guise of the common law or the Constitution.

189 On the origins of “decolonial options" see, eg, Mignolo 2011. 


\section{Purism's politics: An invitation}

From the preceding discussion I hope that it is clear that the stance that we take on whether, as a matter of justice, human rights should impact the common law is influenced by different non-legal factors. If we are to understand each other better, it could help if we are politically as clear as possible about why we take the stand on this issue that we do. Furthermore, it unfortunately seems that often, when scholars say that they support common-law purism on the basis of "legal science and certainty", they use the appearance of personal and legal objectivity to cloak personal politics. We pertinently saw this in the work of LC Steyn and perhaps also in the writings of Potgieter and Visser. With that said, I do not deny that there are scholars who have shown keen interest in determining the "plain meaning" of the Constitution's application provisions without necessarily carrying right wing or politically conservative commitments. One such example is professor Anton Fagan.

As a starting point, it must be highlighted that Fagan does not pertinently ask the question whether it would be a good idea, as a matter of justice, for the Constitution to apply to private common law. Instead, he has focused some of his most important research on the plain meaning of the constitutional text to discover the relationship between different application provisions. Ostensibly relying on the legal positivist philosophy of Hart, Fagan has argued that the common law may be developed for one of three reasons, namely, to give better effect to constitutional rights (following section 8), for the sake of justice (in accordance with section 173) or because of the common law itself (relying on section 39(3)). ${ }^{190}$ Once it is decided that the common law must be developed for one of these three reasons, the spirit, purport and objects of the Bill of Rights (quoted in section 39(2)) kicks in as the standard according to which the development is to take place - in that way, section 39(2) plays a secondary role in the common law's development. ${ }^{191}$ Fagan's exposition of the application provisions disrupted the popular approach to constitutional application in South Africa that made common-law development possible either directly (where the common law was inconsistent with specific rights, according to section 8 ) or indirectly (where the common law fell short of the spirit, purport and objects of the Bill of Rights according to section 39(2))..$^{192}$ Fagan's challenge to the popular constitutional application models was met with fervent criticism from Dennis Davis ${ }^{193}$ and Christopher Roederer ${ }^{194}$ who scolded him for being a naughty positivist. Despite the negative connotations that the term "positivist" might hold in many postcolonial states, ${ }^{195}$ being called a positivist in our time of constitutional

190 Fagan 2010: 622.

191 Idem 621.

192 On these popular models of constitutional application in delict see Loubser \& Midgley 2012: 3335; and Neethling \& Potgieter 2015: 18-22.

193 Davis 2012.

194 Roederer 2013.

195 See, eg, Okafor 1984; Taiwo 1985; and William \& Oke 2008. 
supremacy is not the same as being called a supporter of right-wing politics. Even if we accept that Fagan's reading of the application provisions has a positivist feel, Fagan at no point says that the Constitution should have no impact on private law and gives no indication that he is against positive reforms in private law.

On my interpretation, his silent motive was simply to question whether the conventional direct/indirect application separation was really constitutionally mandated or a strange importation and adaptation of German constitutional law. Even though I do not call myself a positivist, I grant Fagan the necessary interpretative charity and must concede that he has opened up a new way of thinking about the application provisions in the Constitution - and by that I do not say that his interpretation is the correct rendition, but it could surely be one of many acceptable renditions. ${ }^{196}$ To some critical legal scholars, Fagan's relegation of the spirit, purport and objects of the Bill of Rights to a secondary role in common-law development is unacceptable, probably because critics are well known for their passion for flexible standards (such as the spirit, purport and objects of the Bill of Rights) that can easily be manipulated to achieve altruistic or egalitarian aims. Strangely, if I consider how the phrase "spirit, purport and objects of the Bill of Rights" has been used by our courts in the past, a pattern appears that the phrase invariably means "constitutional rights".

In Carmichele the common law was in truth developed because it appeared that it did not afford the victim sufficient protection of her constitutional rights to dignity, bodily integrity, privacy and equality. The same may be said about $K v$ Minister of Safety and Security. ${ }^{197}$ I cannot recall a single case of common-law development in delict where the flexible standard of "spirit, purport and objects" has not been given sole content to by substantive constitutional rights. If this is true, then there is no ostensible difference between common-law development on the ground of "giving effect to constitutional rights" (the direct, liberal model, following section 8) and "falling short of the spirit, purport and objects of the Bill of Rights" (the indirect, critical model, following section 39(2)). Perhaps from a practical point of view there is very little difference between whether we say we develop the common law directly or indirectly. ${ }^{198}$ If this is the case, then Fagan could be right about saying that the "spirit, purport and objects" (factually) do not play a primary role in deciding the foundational question of whether a specific common law provision requires development, and politically it does not really matter whether we want to rely on rights or standards to develop the common law because constitutional rights and standards always go hand in hand in the process of constitutional application - the "progressive" decisions in Carmichele and $K$, that the critics seem to praise as being

196 Similar contentions are raised by Bhana 2008; and Bhana 2013. Friedman 2014 has also become more inclined to follow similar lines of reasoning.

1972005 (6) SA 419 (CC).

198 See, esp, Ferreira 2006. 
beyond reproach, were ultimately not developments made because of "the spirit, purport and objects" but on the basis of a conglomeration of constitutional rights that had to be given effect to. Therefore, it can hardly be said that Fagan's contention (that the spirit, purport and objects of the Bill of Rights only play a secondary role in common-law development) is imbued with conservative politics, even though his approach to the interpretation of texts might be regarded as being conservative.

The avid critical reader of Fagan might turn around and exclaim that there are conservative political sentiments reflected in Fagan's work because he has rejected the use of constitutional rights in Carmichele and $K .{ }^{199}$ Again, I would emphasise that Fagan is not necessarily completely opposed to the idea of constitutional rights impacting private law. What he is chiefly worried about is what he regards as bad understandings of existing common-law rules. Additionally, in the context of both Carmichele and $K$, Fagan's concern about the way in which the Constitution was used relates to who the bearers of constitutional obligations are. For example, according to Fagan, employees of the police do not automatically bear the responsibility of the entire police force. Whether an employee bore a specific duty must be determined with reference to their employment contracts that may or may not incorporate constitutional duties. As I read Fagan, he is concerned about overbroad impositions of constitutional duties on employees of the state - a cleaner in the South African Police Service does not bear the same duty to protect the public as a station commander does, and so both persons cannot be said to bear the same intensity of constitutional duty simply by virtue of the identity of their employer. At times it may appear as though Fagan has little sympathy for the victims of gender-based violence in Carmichele and $K$, with the result that his approach to law is described as being reminiscent of the old order and/or politically conservative. One of the dangers of positivist legal research that only asks "what is the law?" without further endeavouring to ask "what does justice demand?" is that it seems like an implicit approval of the law, no matter how unjust it is. However, Fagan does not have flagrantly conservative politics.

To the contrary, Fagan is one of the founding members of the Five Plus Project that aims to involve "comparatively well-off people" to donate 5 per cent or more of their income to the project that works toward poverty alleviation. ${ }^{200}$ Fagan obviously has an idea of what privilege is and has shown a commitment, in his own way, to transforming South African society. His politics certainly does not have the appearance of right wing or conservative sentiments. In light of the above, it would be interesting to hear Fagan's thoughts on what justice demanded in the cases of Carmichele and $K$, even though he believes that the Constitutional Court got the common law and constitutional application wrong in both cases.

The exposition of Fagan's approach to law and a suggestion about his politics is necessary because, as we have seen in the preceding sections, just because someone

199 Fagan 2008; and Fagan 2009.

200 See University of Cape Town (accessed 14 Mar 2017). 
perhaps appears to be a common-law purist does not necessarily mean that his ideas are not useful or valuable. I have found Fagan's ideas to be particularly useful in making critical sense of the hegemonic direct/indirection constitutional application discourse that still features most prominently in delict scholarship today. I have also found Fagan's ideas to be useful in the critical, egalitarian (re)conceptualisation of vicarious liability and wrongfulness, even though he has a fairly rigid idea of what the law is and what legal interpretation involves (one that I do not necessarily agree with). My invitation to Fagan and other private-law academics is to consider writing something that relates to fundamental, political questions about the application of human rights to private law. For example, in political terms of justice, what are his/her views about the application of constitutional rights to the common law? In political terms of justice, what is the relationship between having a solid law of delict (and a strict model for legal interpretation) and a good society? In political terms of justice, how should we cope with the fact that a really rigid application of the rules relating to vicarious liability and wrongfulness might lead to victims of genderbased violence being left remediless? In fact, is it acceptable for such victims to be left remediless? Perhaps some academics will say that these questions do not matter because, as some strands of positivist theory go, law and justice are two separate concepts that are unrelated to each other. That approach would certainly have a manifest political effect when the strict application of laws produces conservative results. Perhaps some academics will come forward and say, in critical tone, that the law cannot be just or fair and so we should leave justice as a task for the non-lawyers. Or, if the law is unjust, it should not be the task of lawyers to remedy that unfairness.

I am indeed interested to hear what my fellow private-law academics' thoughts are on these issues and whether they believe that there is any link at all between their politics and their approaches to the law-and-justice interface. We are bound to disagree with each other. But that is acceptable and enjoyable because South Africa no longer outlaws difference. As Thorne Godinho has recently argued following Chantal Mouffe, we have to embrace agonistic politics if we want to create a space that is welcoming to a plurality of voices. ${ }^{201}$ If some of our colleagues want to move to Orania that is fine, but they should at least be candid about that fact. We owe it to each other to be politically clear to enhance our understanding of each other's work, to stop lying to ourselves and our students about what we really think about the role of the Constitution for "post"-colonial and "post"-Apartheid South Africa, and to ensure that there is the necessary theoretical depth in our work and thinking.

My invitation has some chutzpah. It would be wrong of me to leave my position on politics and common-law purism unclear. I am a white, middle class, privileged man with a Christian upbringing, born in 1991 amidst many of the debates that I have spoken about in this piece. By the time that I went to school, Mandela was free and I attended integrated schools. I grew up in a fairly liberal household where my English, atheist, Marxist family members were just as welcome as those who 
were German, Satsangi vegetarians. Diversity was acceptable, just as criticism was harshly yet lovingly dished out with the goal of counselling and bettering each other. I saw how my parents took into our house many people who did not have homes. I was taught that giving up certain privileges to care for and love others is not only desirable but imperative. I have always had a predilection for disrupting the pecking order - probably something that I learnt from my grandfather who was a union leader in England many years ago. I received my legal education at the University of Pretoria. That experience exposed me to right-wing conceptions of the law (even as to the role and place of human rights), liberal approaches to law (let us call that human-rights focused education) and more radical paradigms (from classic CLS to decolonial theory). The latter was by far more appealing to me and held the potential for a re-imagination of private law that I thought was stimulating. The knowledgeable professor Johan Scott is my doctoral father who encouraged me to study the common-law rules of delict properly before embarking on any form of critique, but he was nevertheless accommodating of my new ideas. These fun facts about my life - that necessarily paints an incomplete picture of who I am - have shaped my politics in many ways.

Sometimes I get myself into trouble for using Marxist rhetoric in my writing and teaching even though I think Marx was wrong about a lot of things. I think Marx had a point about hierarchy, hegemony and the danger of blind acceptance of all things as normal. I think he was particularly wrong in his economic reductionism. I am interested in the feminist ethic of care - love, altruism and sacrifice are not weird concepts to me. I am conscious of how my race and gender have contributed to a lot of undeserved goodness in my life. I am actively thinking about how to deal with that. I think peaceful coexistence of diverse people is in principle possible, while being mindful of the fact that economic divisions between those people can cause severe tensions that erode peace. These political odds-and-ends link in some way to my approach on the Constitution's influence on the common law.

In my doctoral thesis, ${ }^{202}$ I problematised two extreme approaches to constitutionalising private law.

On the one hand I took issue with constitutional avoidance, that I have labelled "contemporary common-law purism", and which could take of the form on anticonstitutionalism (an active rejection of human rights), ${ }^{203}$ constitutional heedlessness (a passive maintenance of the common-law status quo), ${ }^{204}$ or constitutional deficiency (an attempt at taking the Constitution seriously in private law, while not truly effecting substantive constitutional change). ${ }^{205}$ Constitutional avoidance is problematic, in my view, because the Constitution does have some strategic potential for achieving socially just results in our courts. For example, the enforcement of

202 Zitzke 2016a.

203 See, also, Zitzke 2015a; and a forthcoming follow-up piece Zitzke $2016 \mathrm{~b}$.

204 See, also, Zitzke 2015b.

205 See, also, Zitzke 2016c. 
certain constitutional obligations among non-state actors could give effect to an Africanist conceptualisation of human rights that places individual duty at the centre of a well-functioning society. Human rights do hold some potential to bring about moments of deconstructive-substantive-equality to private relationships in order to fight against privatised apartheid. Lastly, human rights can play an important role in disrupting the hegemony of the common law through the creation of a single system of law subject to a transformative constitution. This does not mean that I uncritically accept the Constitution.

On the other hand, I also took issue with constitutional over-excitement that I defined as a phenomenon when judges or academics use the Constitution as the sole source of law, as if common law, African law and/or legislation do not exist. I suspect that constitutional over-excitement occurs because deducing brand new laws from the Constitution is easier than consulting hundreds of precedents on a specific topic, or simply because some lawyers believe that the Constitution holds the answers to all of our problems. Of course, the Constitution is not always the best panacea for South African people's problems. Following Van der Walt, we might say that constitutional over-excitement has the potential to erode legal pluralism. We might also say that it could lead to really conservative results, because human rights could be used in strongly libertarian ways. Following Ramose, we can also say that the Constitution, despite its potential, has its limits. It is quite clear that this inanimate object has been deified and made supreme, even though it has in many ways failed to give South Africa a decolonial option. I would be slow to say that the Constitution has radically transformed our society and economy in material ways that matter to the most vulnerable and exploited of our community. The Constitution, like all law, is limited in what it can do and we should be open to criticising it just like we might be to the common law.

How should we deal with the common law and its interaction with the Constitution? In the meantime, until paradise comes to the southern tip of Africa, we should venerate neither common law nor the Constitution and we should use whatever tools we have at our disposal to contribute towards realising the needs of the loveless, the poor and other exploited human beings. If the common law as it stands can help us achieve that goal, why not acknowledge that? If the Constitution could be useful for strategic litigation purposes, why not use it? But, at the same time, we should not accept either source of law as necessary, inevitable or perfect and we should be open to rejecting both if needs be. The true decolonial re-imagination of what we call South African private law will, perchance unsurprisingly, require something much more than a simple union of the common law and the Constitution. 


\section{BIBLIOGRAPHY}

Albertyn, Catherine \& Davis, Dennis (2010) "Legal realism, transformation and the legacy of Dugard" South African J on Human Rights 26: 188-216

Anonymous (1982) “'Round and 'round the bramble bush: From legal realism to critical legal scholarship" Harvard LR 95: 1669-1690

Bhana, Deeksha (2008) "The role of judicial method in the relinquishing of constitutional rights through contract" South African J on Human Rights 24: 300-317

Bhana, Deeksha (2013) "The horizontal application of the Bill of Rights: A reconciliation of sections 8 and 39 of the Constitution" South African J on Human Rights 29: 351-375

Boberg, PQR (1966) “Oak tree or acorn?” South African LJ 83: 150-175

Bodenstein, HDJ (1912) "English influences on the common law of South Africa" South African LJ 32: $337-358$

Bophela, Thula (2005) Umkhonto we Siswe: Fighting for a Divided People (Alberton)

Botha, Henk (1994) "Privatism, authoritarianism and the Constitution: The case of Neethling and Potgieter" J of Contemporary Roman-Dutch Law 58: 496-499

Botha, Henk (2004) "Freedom and constraint in constitutional adjudication" SAJHR 20: 249-283

Cameron, Edwin (1982) "Legal chauvinism, executive mindedness and justice - LC Steyn's impact on South African law" South African LJ 99: 38-75

Cameron, Edwin (1993) "Lawyers, language and politics - In memory of JC de Wet and WA Joubert" South African LJ 110: 51-65

Carpenter, Gretchen \& Botha, Christo (1996) "The 'constitutional attack on private law': Are the fears well founded?" J of Contemporary Roman-Dutch Law 59: 126-135

Cherry, Janet (2011) Umkhonto weSiswe (Johannesburg)

Davis, Dennis \& Klare, Karl (2010) "Transformative constitutionalism and the common and customary law" SAJHR 26: 403-509

Davis, Dennis (2012) "How many positivist legal philosophers can be made to dance on the head of a pin? A reply to Professor Fagan" SALJ 129: 59-72

De Wet, JC \& Swanepoel, HL (1949) Strafreg (Durban)

De Wet, JC \& Van Wyk, AH (1978) De Wet en Yeats Die Suid-Afrikaanse Kontraktereg en Handelsreg (Durban)

De Wet, JC (1939) Estoppel by Representation in die Suid-Afrikaanse Reg (University of Stellenbosch)

De Wet, JC (1940) Die Ontwikkeling van die Ooreenkoms ten behoewe van 'n Derde (University of Leiden)

De Wet, JC (1985) De Wet en Swanepoel Strafreg (Durban)

Du Bois, François \& Visser, Daniël (2003) "The influence of foreign law in South Africa" Transnational Law and Contemporary Problems 13: 593-658

Du Bois, François (2004) “The past and present of South African law" International J of Legal Information 32: 217-236

Du Plessis, Jacques \& Lubbe, Gerhard (eds) (2013) Man of Principle: The Life and Legacy of JC de Wet / 'n Man van Beginsel: Die Lewe en Nalatenskap van JC de Wet (Cape Town) 
Du Plessis, Lourens (1990) "Enkele opmerkings oor die Christelike fundering (en verwerping) van menseregte" J of Contemporary Roman-Dutch Law 53: 403-412

Dugard, John (1971) “The judicial process, positivism and civil liberty SALJ 88: 181-200

Dyzenhaus, David (1982) "LC Steyn in perspective” SALJ 99: 380-391

Engle, Eric (2010) “A primer on left legal theory: Realism, Marxism, CLS \& PoMo" The Crit 3: 64-78

Fagan, Anton (2008) "Reconsidering Carmichele" SALJ 125: 659-675

Fagan, Anton (2009) "The confusions of $K$ " SALJ 126: 156-205

Fagan, Anton (2010) "The secondary role of the spirit, purport and objects of the Bill of Rights" SALJ 127: 611-627

Fagan, Eduard (1996) "Roman-Dutch law in its South African historical context" in Zimmermann, Reinhard \& Visser, Daniël Southern Cross: Civil Law and Common Law in South Africa (Oxford) 33-64

Fanon, Frantz (1967) Black Skin White Masks (United Kingdom)

Ferreira, Gerrit (2006) "The direct and indirect application of the Bill of Rights: Constitutional imperative or questionable academic innovation?" Speculum Juris 20: 241-247

Friedman, Nick (2014) "The South African common law and the constitution: Revisiting horizontality" SAJHR 30: 63-88.

Froneman, Johan (2014) “Book review” SALJ 131: 474-480

Gandhi, Mahatma (1961) Non-Violent Resistance: Satyagraha (Schocken)

Gauntlett, Jeremy (ed) (1979) JC Noster: 'n Feesbundel (Durban)

Godinho, Thorne (2016) Responding to Discourses of Consensus: The Possibility of an Empowered, Imaginative Politics in Post-Apartheid South Africa (University of Cape Town)

Habermas, Jürgen (1992) Between Facts and Norms: Contributions to a Discourse Theory of Law and Democracy (Germany)

Hahlo, HR \& Kahn, Ellison (1960) South Africa: The Development of its Laws and Constitution (London)

Hahlo, HR \& Kahn, Ellison (1968) The South African Legal System and its Background (Cape Town)

Hanson, John \& Yosifon, David (2003) "The situation: An introduction to the situational character, critical realism, power economics and deep capture" Univ Pennsylvania LR 152: 129-327

Hathorne, Roy (1952) "Bellum juridicum (2): Open letter to Proculus from the Hon AAR Hathorne" SALJ 69: 23-24

Hoctor, Shanon (2004) "Legal realism" in Roederer, Christopher \& Moellendorf, Darrel Jurisprudence (Cape Town) 158-185

Kahn Ellison (1971) "Retirement of the Chief Justice, Mr LC Steyn" SALJ 88: 1-8

Kennedy, Duncan (1976) "Form and substance in private law adjudication" Harvard LR 89: 16851778

Klare, Karl (1998) "Legal culture and transformative constitutionalism" SAJHR 14: 146-188

Kondlo, Kwandiwe (2009) In the Twilight of the Revolution: The Pan Africanist Congress of Azania (South Africa) 1959-1994 (Switzerland) 
Le Roux, Wessel \& Van Marle, Karin (2004) “Critical Legal Studies” in Roederer, Christopher \& Moellendorf, Darrel Jurisprudence (Cape Town) 246-271

Loubser, Max \& Midgley, Rob (eds) (2012) The Law of Delict in South Africa (Cape Town)

Mathews, AS \& Milton, JRL (1965) “An English backlash” SALJ 82: 31-41

Mignolo, Walter D (2011) "Geopolitics of sensing and knowing: On (de)coloniality, border thinking and epistemic disobedience" Postcolonial Studies 14: 273-283

Modiri, Joel (2013) "Race, realism and critique: The politics of race and Afriforum v Malema in the (In)Equality Court” SALJ 130: 274-293

Mulligan, GA (1952) "Bellum juridicum (3): Purists, pollutionists and pragmatists" SAinvloed van die nuwe Grondwet: Neethling v Du Preez, Neethling v The Weekly Mail 19941 SA 708 (A)" J of Contemporary Roman-Dutch Law 57: 513-519

Neethling, Johann \& Potgieter, Johan (1995) "Aspekte van die lasterreg in die lig van die Grondwet: Gardener v Whitaker 19952 SA 672 (OK)" J of Contemporary Roman-Dutch Law 58: 709-715

Neethling, Johann \& Potgieter, Johan (1997) "Regsonsekerheid in die lasterreg in die lig van die Grondwet - Die pad vorentoe?" J of Contemporary Roman-Dutch Law 60: 706-711

Neethling, Johann \& Potgieter, Johan (2015) Neethling-Potgieter-Visser Law of Delict (Durban)

Neethling, Johann (1971) "Enkele gedagtes oor die juridiese aard en inhoud van menseregte en fundamentele vryhede" J of Contemporary Roman-Dutch Law 34: 240-249

Neethling, Johann (1997) “Die reg op privaatheid en die Konstitusionele Hof: Die noodsaaklikheid vir duidelike begripsvorming” J of Contemporary Roman-Dutch Law 60: 137-143

Neethling, Johann et al (1989) Deliktereg (Durban)

Okafor, FU (1984) "Legal positivism and the African legal tradition" International Philosophical Quarterly 157-164

Potgieter, Johan (1989) “Gedagtes oor die nie-Christelike aard van menseregte" J of Contemporary Roman-Dutch Law 52: 386-408

Potgieter, Johan (1990) "Menseregte: Verwyder die skyn van Christelikheid" J of Contemporary Roman-Dutch Law 53: 413-422

Potgieter, Johan (1991) "The role of law in a period of political transition: The need for objectivity" $J$ of Contemporary Roman-Dutch Law 54: 800-807

Price, TW (1947) "The future of Roman-Dutch law in South Africa” SALJ 64: 494-505

Proculus (1950) "Bellum juridicum: Two approaches to South African law” SALJ 68: 306-313

Ramose, Mogobe B (2007) “In memoriam: Sovereignty and the 'new' South Africa” Griffith LR 16: $310-329$

Roederer, Christopher (2013) "Remnants of apartheid common law justice: The primacy of the spirit, purport and objects of the bills of rights for developing the common law and bringing horizontal rights to fruition" SAJHR 29: 219-250

Rumpff, FLH (1978) “'n Waardering van die bydrae tot die ontwikkeling van die regswetenskap in die appèlhofuitsprake van hoofregter LC Steyn" J of South African Law 87-106

Simpson, Thula (2016) Umkhonto we Siswe: The ANC's Armed Struggle (Cape Town)

Singer, Joseph (1988) "Legal realism now" California LR 76: 465-544 


\section{EMILE ZITZKE}

Snyman, CR (2013) “JC de Wet se bydrae tot die Suid-Afrikaanse strafreg” in Du Plessis, Jacques \& Lubbe, Gerhard (eds) Man of Principle: The Life and Legacy of JC de Wet I 'n Man van Beginsel: Die Lewe en Nalatenskap van JC de Wet (Cape Town) 351-375

South African Law Commission (1991) Interim Report on Group and Human Rights (South Africa)

Taiwo, Olufemi (1985) "Legal positivism and the African legal tradition: A reply" International Philosophical Quarterly 25: 197-200

Tamanaha, Brian (2009) "Understanding legal realism” Texas LR 87: 732-785

Terreblanche, Sampie (2002) A History of Inequality in South Africa 1652-2002 (Scottsville)

Thomas, PhJ et al (2000) Historical Foundations of South African Private Law (Durban)

Thompson, Leonard (2014) A History of South Africa: From the Earliest Known Human Inhabitation to the Present (Johannesburg)

Tushnet, Mark (1991) “Critical legal studies: A political history” Yale LJ 100: 1515-1544

Tyson, Lois (2006) Critical Theory Today: A User-Friendly Guide (New York)

Unger, Roberto Mangabeira (1983) “The critical legal studies movement" Harvard LR 96: 561675

University of Cape Town (accessed 14 March 2017): “The Five Plus Project: Helping to Reduce and Alleviate Poverty in South Africa" available at http://www.fiveplus.uct.ac.za/

Van Blerk, Adrienne (1982) "The irony of labels" SALJ 99: 365-379

Van Blerk, Adrienne (1996) "Critical legal studies in South Africa" SALJ 113: 86-108

Van Blerk, Adrienne (1998) Jurisprudence: An Introduction (Durban)

Van der Walt, Johan (2014) The Horizontal Effect Revolution and the Question of Sovereignty (Berlin)

Van Doren, John (1989) "Critical legal studies and South Africa” SALJ 106: 648-665

Van Niekerk, Barend "JC Noster: A review and tribute to Professor JC de Wet" (1980) 97 SALJ 183-188

Van Niekerk, Gardiol (2011) "The endurance of the Roman tradition in South African law" Studia Universitatis Babeş-Bolyai Jurisprudentia 4: 20-33

Van Wyk, Andreas (2013) "JC de Wet as Universiteitsman en Stellenbosse Burger" in Du Plessis, Jacques \& Lubbe, Gerhard (eds) Man of Principle: The Life and Legacy of JC de Wet / 'n Man van Beginsel: Die Lewe en Nalatenskap van JC de Wet (Cape Town) 39-50

Van Zyl, DH (1971) Geskiedenis van die Romeins-Hollandse Reg (Durban)

Visser, Daniël (1986) "Daedalus in the supreme court - the common law today" J of Contemporary Roman-Dutch Law 49: 127-138

Visser, Daniël (1989) "The legal historian as subversive, or: Killing the Capitoline Geese" in Visser, Daniël (ed) Essays on the History of Law (Cape Town) 21-22

Visser, Daniël (2003) "Cultural forces in the making of mixed legal systems" Tulane LR 78: 41-78

Visser, Hans \& Potgieter, Johan (1994) "Some critical comments on South Africa's bill of fundamental rights" J of Contemporary Roman-Dutch Law 57: 493-498

Visser, Hans (1995a) "Enkele gedagtes oor fundamentele regte en die familie" J of Contemporary Roman-Dutch Law 58: 702-708 
Visser, Hans (1995b) "A successful constitutional invasion of private law: Gardener $v$ Whitaker 19952 SA 672 (E)” J of Contemporary Roman-Dutch Law 58: 745-750

Visser, Hans (1996a) “Geen afsonderlike eis om 'grondwetlike skadevergoeding' nie" $J$ of Contemporary Roman-Dutch Law 59: 695-700

Visser, Hans (1996b) "Horisontaliteit van fundamentele regte afgewys" $J$ of Contemporary Roman-Dutch Law 59: 510-514

Visser, Hans (1997a) "Enkele beginsels en gedagtes oor die horisontale werking van die nuwe Grondwet" J of Contemporary Roman-Dutch Law 60 : 296-303

Visser, Hans (1997b) "Enkele gedagtes oor die moontlike invloed van fundamentele regte ten aansien van die fisies-psigiese integriteit op deliktuele remedies" J of Contemporary RomanDutch Law 60: 495-405

Wegman, Cornelis (1985) Psychoanalysis and Cognitive Psychology: A Formalization of Freud's Earliest Theory (Orlando)

Wessels, John (1920) “The future of Roman-Dutch law in South Africa” SALJ 37: 265-284

White, G Edward (1986) "From realism to critical legal studies: A truncated intellectual history" Southwestern LJ 40: 819-843

William, Idowu \& Oke, Moses (2008) "Multiculturalism, legal pluralism and the separability thesis: A postmodern critique of 'An African Case for Legal Positivism"” Law, Social Justice \& Global Development 1-28

Woolman, Stu \& Swanepoel, Jonathan (2014) "Chapter 2: Constitutional History" in Woolman, Jonathan \& Bishop, Michael Constitutional Law of South Africa (Cape Town)

Zitzke, Emile (2014) "Stop the illusory nonsense! Teaching transformative delict" Acta Academica 46: $52-76$

Zitzke, Emile (2015a) “RH v DE 2014 (6) SA 436 (SCA): A case of anti-constitutionalism in common-law development" De Jure 48: 467-480

Zitzke, Emile (2015b) "Avoiding two extremes: Constitutional avoidance and over-excitement in the common law's development" Constitutional Court Review Volume 7 Conference Paper (copy on file with author)

Zitzke, Emile (2016a) A New Proposed Constitutional Methodology for Effecting Transformation in the South African Law of Delict (University of Pretoria)

Zitzke, Emile (2016b) "A brief note on the primacy of the Constitution in the common law's development: DE v RH CT 182/14 (2015) ZACC 18” Southern African Public Law (forthcoming in 2016(2))

Zitzke, Emile (2016c) "Realist evolutionary functionalism and extra-constitutional grounds for developing the common law of delict: A critical analysis of Heroldt $v$ Wills 2013 (2) SA 530 (GSJ)" J of Contemporary Roman-Dutch Law 79: 103-120

\section{Cases}

Barkuizen v Napier 2007 (5) 323 (CC)

Campbell v Hall (1774) 1 Cowp 204, 98 ER 1045

Carmichele v Minister of Safety and Security 2001 (4) SA 938 (CC) 


\section{EMILE ZITZKE}

Cassem v Oos-Kaapse Komitee van die Groepsgebiederaad 1959 (3) SA 651 (A)

Certification of the Amended Text of the Constitution of South Africa, 19961997 (2) SA 97 (CC)

Certification of the Constitution of the Republic of South Africa, 19961996 (4) SA 744 (CC)

Collins $v$ Minister of the Interior 1957 (1) SA 552 (A)

Down v Malan NO 1960 (2) SA 734 (A)

Du Plessis v De Klerk 1996 (3) 850 (CC)

Fose v Minsiter of Safety and Security 1996 (2) BCLR 232 (W)

Group Areas Development Board v Hurley NO 1961 (1) SA 123 (A)

Holland $v$ Scott (1882) 2 E.D.C. 307

Kv Minister of Safety and Security 2005 (6) SA 419 (CC)

Laval EU: Case C-341/05 [2007]

Lekhari v Johannesburg City Council 1956 (1) SA 552 (A)

Loza v Police Station Commander, Durbanville 1964 (2) SA 545 (A)

Luxembourg EU: Case C-319/06 [2008]

Minister of Home Affairs v Fourie 2006 (1) SA 524 (CC)

Minister of the Interior v Lockhat 1961 (2) SA 587 (A)

Minister of the Interior $v$ Machadodorp Investments 1957 (2) SA 392 (A)

Potgieter v Kilian 1995 (1) BCLR 1498 (N)

Publications Control Board v William Heinemann 1965 (4) SA 137 (A)

Regal v African Superslate 1963 (1) SA 102 (A)

Rossouw v Sachs 1964 (2) SA 551 (A)

Rüffert EU: Case C-346/06 [2008]

$S v$ Bernardus 1965 (3) SA 287 (A)

Schermbrucker $v$ Klindt NO 1965 (4) SA 606 (A)

South African Defence and Aid Fund v Minister of Justice 1967 (1) SA 263 (A)

Viking EU: Case C-438/05 [2007]

\section{Legislation}

Civil Union Act 17 of 2006

Constitution of the Republic of South Africa Act 200 of 1993

Constitution of the Republic of South Africa, 1996

South Africa Act of 1909 (9 Edw VII c 9) 